\title{
Environmental heterogeneity at different scales: key factors affecting caddisfly larvae assemblages in standing waters within a lowland river catchment
}

\author{
Edyta BUCZYŃSKA, ${ }^{1}$ Stanisław CZACHOROWSKI, ${ }^{2}$ Paweł BUCZYŃSKI, ${ }^{3 *}$ Joanna PAKULNICKA,${ }^{2}$ Edyta STĘPIEŃ, ${ }^{4}$ \\ Agnieszka SZLAUER-ŁUKASZEWSKA, ${ }^{5}$ Robert STRYJECKI, ${ }^{1}$ Andrzej ZAWAL ${ }^{5}$
}

\begin{abstract}
${ }^{1}$ Department of Zoology, Animal Ecology and Wildlife Management, University of Life Sciences, Akademicka 13, 20-033 Lublin; ${ }^{2}$ Department of Ecology and Environmental Protection, University of Warmia and Mazury in Olsztyn, Plac Łódzki 3, 10-727 Olsztyn; ${ }^{3}$ Department of Zoology, Maria Curie-Skłodowska University, Akademicka 19, 20-033 Lublin; ${ }^{4}$ Department of Plant Taxonomy and Phytogeography, University of Szczecin, Wąska 13, 71-415 Szczecin; ${ }^{5}$ Department of Invertebrate Zoology and Limnology, University of Szczecin, Wąska 13, 71-415 Szczecin, Poland
\end{abstract}

*Corresponding author: pawbucz@gmail.com

\begin{abstract}
We examined the importance of environmental parameters at different spatial scales influencing the occurrence of caddisfly larvae at different levels of their organization (species, faunistic metrics and functional groups) in lentic floodplain waters, in order to gain information on the ecological status and management of a small lowland river catchment. At the lowest spatial level - $\mathrm{pH}$, sediment grain size, insolation and the presence of aquatic macrophytes proved significant for caddisfly larvae, at higher and the highest level (including buffer zones and the catchment) - the surface areas of watercourses and the river, distance from standing waters and distance from broadleaf forests, respectively. Rheophilous hydropsychids accounted for $17 \%$ of the whole fauna of the examined water bodies. They spread from the river via water during flood in the spring. We also detected some significant correlations between functional groups of caddisfly larvae and parameters describing buffer zones and the river catchment against the sub-catchment type use. Information provided by the Caddisfly Habitat Index showed an overall good ecological status of the river-floodplain. Caddisfly larvae may be good indicators of numerous factors and processes, but they should be studied comprehensively, at different levels of organization. Our results can be useful for preservation of biodiversity and management of river valleys. We suggest: 1) maintaining the varied structure of aquatic macrophytes in water bodies, 2) securing the long-term presence of broadleaf trees in buffer zones in order to provide detritus input, varied insolation and shelter for caddisflies, 3) limiting drainage activities in the river valley in order to save varied habitats, especially temporary ones, 4) providing heterogeneous landscape in the river catchment (homogenous land use is inappropriate).
\end{abstract}

Key words: Trichoptera; spatial scale; environmental heterogeneity; landscape; lateral connectivity.

Received: June 2016. Accepted: November 2016.

\section{INTRODUCTION}

Environmental heterogeneity is a concept which finds itself at the center of interest in landscape ecology. It is a key aspect of this discipline, together with connectivity and scale (Allan, 2004), and also one of the primary factors influencing biodiversity and species richness patterns within a region, together with species-area relationships and disturbance regimes (Johnson and Host, 2010). Many studies have dealt with describing interactions between measures of environmental heterogeneity and living organisms in both terrestrial and aquatic habitats. Research in this field has been conducted at various geographical scales (from global to local) and at various levels of organization of plants and animals (species, assemblages, and ecological metrics). It is generally confirmed that high environmental heterogeneity leads to high species diversity (Verberk et al., 2006), improving ecosystem functioning and nature preservation.
For the occurrence of aquatic invertebrates, physicochemical variables of the water or structural variables of the water body are generally considered to be important. In recent years, however, the role of landscape features has gained in importance (Bis et al., 2000; Palmer et al., 2000; Mykrä et al., 2004; Bonada et al., 2005; Heino et al., 2008; Cortes et al., 2011; Aschonitis et al., 2016). This is aided by the development of GIS, which make it possible to fairly easily obtain an increasing amount of comparable information on landscape features at large scales (Galbraith et al., 2008; Heino et al., 2008; Johnson and Host, 2010; Ligeiro et al., 2013; Kusch, 2015).

In order to study the role of environmental heterogeneity on the occurrence of species, caddisfly larvae may be a very suitable species group, due to their abundance in many habitats, their diversified modes of life, and their pronounced response to various environmental parameters and transformations or disturbances of the environment (Goretti et al., 1995; Heino, 2000; Brand and Miserendino, 2011; Van den Brink et al., 2013a; Kalaninová 
et al., 2014). For investigating the importance of specific environmental parameters, including landscape variables, on the occurrence of caddisfly larvae, river ecosystems form a suitable study area because of the presence of distinct habitats: the main watercourse, its tributaries, and especially various types of standing water bodies in its catchment. It is the landscape variation of river ecosystems that ensures a large array of environmental parameters. Most studies on caddisfly larvae in river ecosystems have focused on the main river, while relatively few studies have dealt with standing water bodies in the catchment. In a river system, caddisfly larvae may easily penetrate all different types of water bodies by active migration or passive dispersion via floods. Therefore, we should study their occurrence in the river and its neighboring water bodies together and take into account all standing water bodies, particularly in terms of biodiversity patterns of riverine systems, river integrity and the hydrological connectivity gradient (Waringer and Graf, 2002; Van den Brink et al., 2013a, 2013b). These aspects are important for maintaining biodiversity (Duelli, 1997), good environmental conditions (Chovanec et al., 2005), or successful restoration of biodiversity in river ecosystems (Verberk et al., 2006).

It is essential to recognize the mechanisms underlying the relationships between local or regional environmental variability and species diversity. While there is a great deal of data on the effect of various environmental parameters at different scales on the occurrence of caddisfly larvae of rivers (Arscott et al., 2003; Bonada et al., 2005; Urbanič and Toman, 2007; Galbraith et al., 2008; Skuja and Spungis, 2010; Ruiz-García et al., 2012; Savić et al., 2013; Kalaninová et al., 2014), there is little of such information on the standing water bodies in river valleys (Van den Brink et al., 2013a, 2013b). Although the fauna of such water bodies is often considered to be highly variable and unpredictable (Friday, 1987), and therefore difficult to study, these lentic habitats are distinguished by a highly widespread and diversified caddisfly fauna, frequently dominated by the largest family, Limnephilidae (Hering et al., 2009). Information on the role of landscape parameters on the occurrence of caddisfly larvae in these riverine habitats is very sparse. However, such information may be important for an understanding of the relationships, processes and changes taking place in the entire river system.

Landscape parameters include different types of management in the catchment. According to Waldhardt (2003), land use intensities must be taken into account in analyzing biodiversity and landscape relationships. Brand and Miserendino (2011) investigated how contrasting land use in Argentina affects caddisfly larvae and found that they can be used as an early warning tool to assess changes in disturbed headwater systems. Assuming that catchment parameters determine the occurrence of macroinvertebrates (Galbraith et al., 2008; Cortes et al., 2011; Gombeer et al., 2011), it is worth to study whether caddisfly larvae may reflect a gradient of habitat transformations from the least transformed (natural) areas to the most transformed (man-made) ones, and whether specific variables can be identified which determine the occurrence of caddisfly larvae in a given catchment type.

In order to contribute to a better recognition of drivers of caddisfly larvae diversity in poorly known lentic water bodies in river ecosystems, and to provide information on the ecological recognition of catchment environments, in order to preserve these river ecosystems, we studied the following aspects. 1) Can assemblages and functional groups (FG) of caddisfly larvae be related to different types of standing water bodies in a river catchment? 2) How does the origin and distribution of standing water bodies and the flowing river influence the occurrence caddisfly larvae of standing water bodies in the catchment? 3) Which group of variables (physicochemical, hydrological, structural or landscape) can be related to caddisfly larvae assemblages in these water bodies and which are the key parameters in each of these groups? 4) Does subcatchment use, in a gradient from the most natural (forest) to the most modified (agricultural), influence caddisfly larvae distribution in standing water bodies? 5) Which conclusions can be drawn about to the general ecological condition of the river catchment and which regarding the preservation of hydrological lateral connectivity of the water bodies in the river-floodplain?

\section{METHODS}

\section{Study area and sampling}

Samples were collected from standing water bodies in the valley of the small lowland River Krąpiel (north-western Poland) (Fig. 1). This is a small watercourse, $70 \mathrm{~km}$ long, flowing in an incised valley through an area with different land use types. Floods occur in this valley every few or several years. The valley was divided into 13 segments (sub-catchments), within which sampling sites were designated on the river itself and in the neighboring standing water bodies. The water bodies studied differed in origin, size and permanence, and included oxbows (11 sites), small water bodies (9), springs (3), alder carrs (6), sedge marshes (4) and riverine marshes (5). The different numbers of water bodies in each category were due to their varied frequency of occurrence in the valley of the Krapiel. Field work was conducted from April to October 2010. In this year, flood ended at the beginning of May, just before the second sampling. Three subsamples were collected with a kick-net hydrobiological sampler on each sampling occasion for variability analyses. Each sampling 
consisted of 10 energetic sweeps covering an area of about $0.5 \mathrm{~m}^{2}$. A combined 253 samples were collected from 38 sites. Caddisfly larvae were found to be present at $80 \%$ of all sites and in $50 \%$ of all samples; they were not noted only in the water bodies of sub-catchments K11 and $\mathrm{K} 13$, therefore these latter sub-catchments were excluded from further analysis (Fig. 1). Basic environmental parameters of the particular study sites along the valley of the river are given in Tab. 1.

During the same study period separate samples of caddisfly larvae were taken at 45 sites within the river ( 28 current and 17 marginal pool sub-habitats) in the 13 sub-catchments. All collected caddisfly larvae were identified to species level as much as possible with the use of Edington and Hildrew (1995), Wallace et al. (2003), Waringer and Graf (2011). Qualitative and quantitative data on occurrence and relative abundance of caddisfly larvae at these sites obtained during this sampling (Supplementary Tab. 1) were used in order to compare with the corresponding data on the occurrence and relative abundance of caddisfly larvae in the standing water bodies.

At each sampling site 11 physicochemical water parameters were measured (Tab. 2), with an Elmetron CX-
401 multiparametric sampling probe and a Slandi LF205 photometer. Three measurements were performed each time and the mean values were used for further analyses. In addition, 8 structural parameters were determined for each site (Tab. 2). Analysis of the landscape in 13 subcatchments of the river valley was based on buffer zones and catchments assigned to each sampling site (K1-K14). The buffer zone was marked out as a circle around the sampling site with a radius of $500 \mathrm{~m}$. The catchment of the given study site was defined as a catchment limited by two subsequent macrohabitats. The analysis of the spatial structure of the buffer zones and catchments was based on a set of landscape metrics calculated with the help of TNTmips software by the company MicroImages. Classification was based on Landsat TM7 28-05-2003 data; edges and linear elements based on a 1:10 000 scale map; classes according to CORINE classification - in case of meadows, simplified classes were applied (merged meadows and pastures due to the minimal share of pastures in the studied area; repeated isoclass using the class merging option in accordance with the dendrogram; completed with drawing vectors to mark class edges). Rivers, roads and drainage trenches are marked as polygons of an

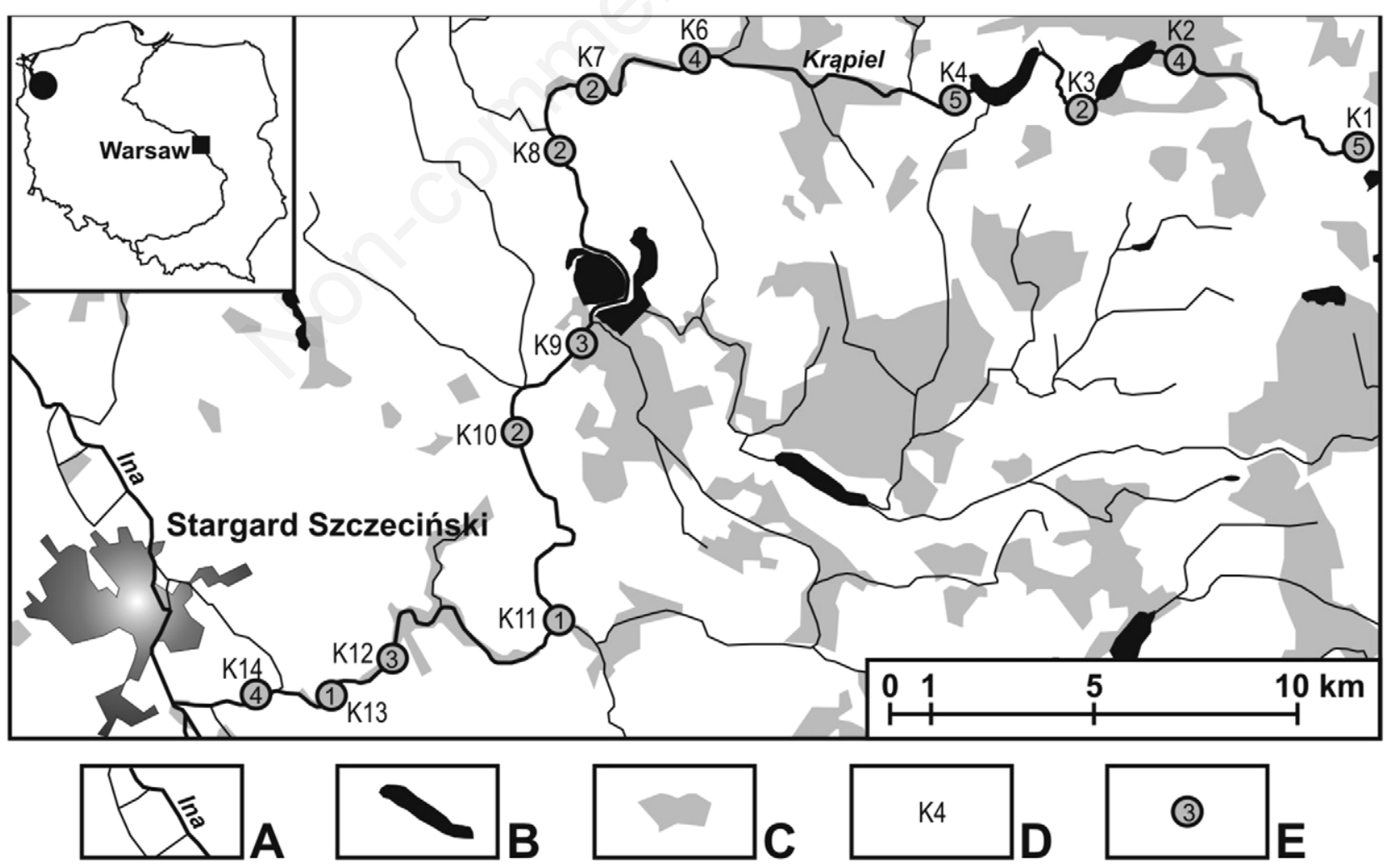

Fig. 1. Locations of sampling sites. A, rivers; B, lakes and fish ponds; C, forests; D, sub-catchment; E, number of sites studied within a sub-catchment. 
area of at least $200 \mathrm{~m}$. GPS was applied to determine the coordinates of sampling sites, with the site area defined by a $500-\mathrm{m}$ radius. Upon an analysis of the obtained data, only those landscape parameters were selected that proved to be statistically significant in terms of fauna distribution $(p<0.05)$. All landscape parameters, for both buffer zones and the entire catchment are presented in Tab. 2.

\section{Faunistic indices and statistical analyses}

In the analysis of caddisfly larvae, in addition to the species level we also took into account functional groups in relation to their current preferences and hydrological preferences. We used categories described in the literature (Chovanec et al., 2005; Graf et. al., 2008), with modifica-

Tab. 1. Characteristics of the study sites along the valley of the River Krąpiel.

\begin{tabular}{|c|c|c|c|c|c|c|c|c|}
\hline SC & WT & Bottom & DE & PL & LT & DR & $\mathrm{PE}$ & Hydrological connectivity \\
\hline K1 & $\mathrm{RM}$ & $\min$ & 0.5 & 5 & MIX-FOR & 5 & 4 & Temporary habitat* \\
\hline K1 & $\mathrm{RM}$ & $\min$ & 0.1 & 5 & MIX-FOR & 5 & 4 & Temporary habitat * \\
\hline $\mathrm{K} 1$ & $\mathrm{PO}$ & org, lea & 1 & 0 & MIX-FOR & 10 & 7 & Permanent habitat * \\
\hline K1 & $\mathrm{PO}$ & org, lea & 0.1 & 0 & MIX-FOR & 10 & 7 & Permanent habitat* \\
\hline K1 & SM & min, org & 0.2 & 5 & MIX-FOR & 10 & 7 & Permanent habitat * \\
\hline $\mathrm{K} 2$ & $\mathrm{PO}$ & $\min$ & 0.2 & 3 & MIX-FOR & 5 & 2 & Temporary habitat* \\
\hline $\mathrm{K} 2$ & $\mathrm{PO}$ & $\min$ & 0.1 & 1 & MIX-FOR & 5 & 2 & Temporary habitat* \\
\hline $\mathrm{K} 2$ & $\mathrm{PO}$ & min, org, lea & 0.2 & 0 & MIX-FOR & 5 & 2 & Temporary habitat* \\
\hline $\mathrm{K} 2$ & $\mathrm{PO}$ & min, org, lea & 0.1 & 0 & MIX-FOR & 5 & 2 & Temporary habitat* \\
\hline $\mathrm{K} 3$ & SP & $\min$, org & 0.1 & 5 & MIX-FOR & 5 & 2 & Temporary, no connection with MC \\
\hline $\mathrm{K} 3$ & SP & min, org, lea & 0.1 & 3 & MIX-FOR & 5 & 2 & Temporary, no connection with MC \\
\hline K4 & SM & min, org & 0.2 & 5 & MIX-AGR & 15 & 3 & Temporary habitat* \\
\hline K4 & $\mathrm{AC}$ & org, lea & 0.4 & 1 & MIX-AGR & 20 & 2 & Temporary habitat* \\
\hline K4 & $\mathrm{AC}$ & org, lea & 0.1 & 1 & MIX-AGR & 20 & 2 & Temporary habitat* \\
\hline $\mathrm{K} 4$ & $\mathrm{PO}$ & org & 0.5 & 0 & MIX-AGR & 20 & 3 & Temporary habitat \\
\hline K4 & $\mathrm{PO}$ & org & 0.1 & 0 & MIX-AGR & 20 & 3 & Temporary habitat \\
\hline K6 & OX & $\min$, lea & 1 & 0 & MIX-AGR & 40 & 7 & No permanent connection with $\mathrm{MC}^{*}$ \\
\hline K6 & OX & $\min$, lea & 0.1 & 0 & MIX-AGR & 40 & 7 & No permanent connection with $\mathrm{MC}^{*}$ \\
\hline K6 & $\mathrm{AC}$ & org, lea & 0.2 & 0 & MIX-AGR & 10 & 2 & Temporary habitat* \\
\hline K6 & $\mathrm{AC}$ & org, lea & 0.1 & 0 & MIX-AGR & 10 & 2 & Temporary habitat* \\
\hline $\mathrm{K} 7$ & $\mathrm{PO}$ & min, lea & 0.1 & 0 & MIX-AGR & 15 & 2 & Temporary habitat* \\
\hline K7 & $\mathrm{OX}$ & min, org, lea & 0.2 & 0 & MIX-AGR & 10 & 2 & No permanent connection with $\mathrm{MC}^{*}$ \\
\hline K8 & $\mathrm{RM}$ & org & 0.5 & 4 & AGR & 5 & 7 & Permanent habitat* \\
\hline K8 & $\mathrm{RM}$ & org & 0.1 & 5 & AGR & 5 & 7 & Flooded till May, permanent habitat \\
\hline K9 & SM & org & 0.2 & 5 & MIX-FOR & 10 & 2 & Temporary habitat* \\
\hline K9 & $\mathrm{AC}$ & min, org, lea & 0.4 & 0 & MIX-FOR & 20 & 3 & Temporary habitat* \\
\hline K9 & $\mathrm{AC}$ & min, org, lea & 0.1 & 0 & MIX-FOR & 20 & 3 & Temporary habitat* \\
\hline K10 & $\mathrm{OX}$ & org & 0.7 & 3 & AGR & 3 & 7 & Connected at one end with MC, no current (muddy)* \\
\hline K10 & OX & org & 0.1 & 5 & AGR & 3 & 7 & Connected at one end with MC, no current (muddy)* \\
\hline K11 & $\mathrm{RM}$ & org & 0.1 & 0 & MIX-AGR & 2 & 1 & Temporary habitat* \\
\hline K12 & OX & org, lea & 0.4 & 1 & AGR & 10 & 7 & No permanent connection with $\mathrm{MC}^{*}$ \\
\hline K12 & OX & org, lea & 0.1 & 0 & AGR & 10 & 7 & No permanent connection with $\mathrm{MC}^{*}$ \\
\hline K12 & SP & org, lea & 0.1 & 1 & AGR & 10 & 7 & rain fed mainly, permanent habitat \\
\hline K13 & SM & $\min$ & 0.4 & 4 & AGR & 5 & 2 & temporary habitat* \\
\hline K14 & $\mathrm{OX}$ & $\min$ & 0.7 & 0 & AGR & 10 & 2 & No permanent connection with $\mathrm{MC} *$ \\
\hline K14 & OX & $\min$ & 0.1 & 0 & AGR & 10 & 2 & No permanent connection with $\mathrm{MC}^{*}$ \\
\hline K14 & OX & $\min$ & 0.4 & 0 & AGR & 15 & 2 & No permanent connection with $\mathrm{MC}^{*}$ \\
\hline K14 & OX & $\min$ & 0.1 & 0 & AGR & 15 & 2 & No permanent connection with $\mathrm{MC}^{*}$ \\
\hline
\end{tabular}

$\overline{S C}$, sub-catchment (numbering like in the Fig. 1); WT, water body type [OX, oxbows; RM, riverine marshes; PO, small water bodies (pools); SM, sedge marshes; AC, alder cars; SP, springs]; Bottom: min, mineral; lea, leaves; org, organic; DE, depth (m); PL, plants; LT, main landscape type in the subcatchment (AGR, agricultural landscape type; MIX-AGR, mixed landscape type with dominance of cropland; MIX-FOR, mixed landscape type with dominance of forests); DR, distance from the river (m); PE, permanence (months); MC, main channel; * sites affected by flood till the beginning of May. 
tions for Polish caddisfly fauna applied by Czachorowski (Czachorowski, 1998) and based on the first author's own data base. The categories were as follows. For current preference: limnobionts (LB) - species inhabiting standing waters only; limnophiles (LP) - species usually inhabiting standing waters, rarely occurring in slow-flowing courses; rheo-limnophiles (RL) - species usually inhabiting flowing courses (slow-flowing or lentic zones), but also occurring in standing waters; rheophiles (RP) - species occurring in streams, usually with a moderate current; and rheobionts (RB) - species occurring in fast flowing waters only. For hydrological preferences: eupotamon (EUP) - species inhabiting the (lotic) main channel and connected (lotic) side arms; parapotamon (PRP) - species inhabiting side arms connected only at the downstream end at mean water lev- els; plesiopotamon (PLP) - species occurring in waters with no direct connectivity with the main channel (but more or less frequently connected in times of floods), coverage by macrophytes $<20 \%$; paleopotamon (PAP) - species occurring in waters with no direct connectivity with the main channel (but seldomly connected in times of floods), coverage by macrophytes $>20 \%$; TMP - species inhabiting temporary waters. These hydrological categories were used in calculating the Caddisfly Habitat Index (CHI) proposed by Waringer and Graf (2002), as a tool applicable at different spatial scales (from sites to river catchments). Abundances of caddisfly larvae were incorporated in the formula, based on the dominance classes previously distinguished. This index provides information on the ecological integrity and connectivity patterns of a river-floodplain system. In

Tab. 2. Environmental variables recorded at each sampling site, abbreviations used in RDAs, measurement units (Mu) and ranges and mean with standard deviations. Variables in bold were used in RDAs - the remaining ones were excluded from the further analyses due to collinearity.

\begin{tabular}{|c|c|c|c|}
\hline Variable & Abbreviation & Mu & Ranges (Mean with SD) \\
\hline \multicolumn{4}{|l|}{ Physicochemical variables } \\
\hline Oxygen content & $\mathrm{O}_{2}$ & $\mathrm{mg} \mathrm{dm}{ }^{-3}$ & $4.9 \pm 3.8(0.2-16.1)$ \\
\hline pH & pH & & $6.3 \pm 1.2(2.1-8.3)$ \\
\hline Temperature & temp & ${ }^{\circ} \mathrm{C}$ & $14.6 \pm 4.5(7.6-23.9)$ \\
\hline Electric conductivity & cond & $\mu \mathrm{S} \mathrm{cm}{ }^{-1}$ & $214 \pm 91.4(55-524)$ \\
\hline Ammoniacal nitrogen & NH4 & $\mathrm{mg} \mathrm{dm} \mathrm{m}^{-3}$ & $1.0 \pm 0.8(0.1-4.8)$ \\
\hline Nitric nitrogen & NO3 & $\mathrm{mg} \mathrm{dm} \mathrm{dm}^{-3}$ & $1.1 \pm 1.5(0.4-8.2)$ \\
\hline Phosphates & PO4 & $\mathrm{mg} \mathrm{dm} \mathrm{dm}^{-3}$ & $0.5 \pm 0,6(0.1-3.6)$ \\
\hline $\mathrm{Fe}$ & $\mathrm{Fe}$ & $\mathrm{mg} \mathrm{dm} \mathrm{dm}^{-3}$ & $1.6 \pm 12.4(0.0-102.0)$ \\
\hline Turbidity & turb & $\mathrm{mg} \mathrm{dm}{ }^{-3}$ & $37.7 \pm 75.1(0.0-304.0)$ \\
\hline Hardness & hard & $\mathrm{mg} \mathrm{CaCO} \mathrm{dm}^{-3}$ & $156.6 \pm 75.1(6.8-412.0)$ \\
\hline Biochemical oxygen demand & BOD5 & $\mathrm{mg} \mathrm{dm}{ }^{-3}$ & $3.7 \pm 2.1(0.0-10.3)$ \\
\hline \multicolumn{4}{|l|}{ Structural variables } \\
\hline Insolation & INSO & $\%$ & $47.7 \pm 38.9(0.2-100.0)$ \\
\hline Content of mineral sediment & MIN_MAT & $\%$ & $61.4 \pm 25.4(13.4-96.9)$ \\
\hline Content of organic sediment & ORG_MAT & $\%$ & $38.5 \pm 25.4(3.1-86.6)$ \\
\hline Mean sediment grain size & $\overline{\mathbf{M}}$ & $\%$ & $1.1 \pm 0.8(-0.52-2.40)$ \\
\hline Sediment sorting & W & - & $1,46 \pm 0.40(0.69-2.09)$ \\
\hline Overgrowth with aquatic vegetation & plants & 0 (no plants) -5 (complete overgrown) & $2.1 \pm 2.3(0-5)$ \\
\hline Permanence of a water body & perman & number of months with water & $5,3 \pm 2.3(2-7)$ \\
\hline Distance from the river & distance & $\mathrm{m}$ & $13.7 \pm 11.6(3-40)$ \\
\hline \multicolumn{4}{|l|}{ Landscape variables: metrics of buffer zones } \\
\hline Mean patch size & MPS & ha & $1.81 \pm 0.77(0.95-3.57)$ \\
\hline Patch size standard deviation & PSSD & ha & $3.28 \pm 1.39(1.45-5.37)$ \\
\hline Median of patch sizes & MEDPS & ha & $0.51 \pm 0.16(0.21-0.74)$ \\
\hline Number of patches & NUMP & - & $50.8 \pm 18.8(22-83)$ \\
\hline Total edge length & TE & $\mathrm{m}$ & $33856.9 \pm 5821.4(25342-43174)$ \\
\hline Mean edge length & MTE & $\mathrm{m}$ & $726.7 \pm 186.5(520-1152)$ \\
\hline Sum of patch shape indices & SUM & - & $97.17 \pm 27.47(48.35-138.32)$ \\
\hline Mean shape index & MSI & - & $1.98 \pm 0.20(1.67-2.27)$ \\
\hline Shannon's patch diversity index & SDI & - & $2.05 \pm 0.15(1.54-2.20)$ \\
\hline Shannon evenness index & SEI & - & $0.87 \pm 0.03(0.83-0.92)$ \\
\hline Contagion & $\mathrm{C}_{\mathrm{R}}$ & - & $2.30 \pm 0.98(1.20-4.55)$ \\
\hline Edge density & ED & $\mathrm{m} / \mathrm{ha}$ & $431.04 \pm 73.96(322.88-549.15)$ \\
\hline Patch density & PD & number of patches $/ 100$ ha & $64.72 \pm 23.87(28.03-105.57)$ \\
\hline
\end{tabular}


addition, it can be useful in estimating the ecological status of the entire river-floodplain system in the light of WFD guidelines (Chovanec et al., 2005).

$$
\mathrm{CHI}=\frac{\Sigma(\mathrm{HV} \times \mathbf{A} \times \mathrm{IW})}{\Sigma(\mathrm{A} \times \mathrm{IW})}
$$

$\mathrm{HV}$ - the species-specific habitat value

A - the abundancy class

IW - indication weight
The dominance index, with classes according to Biesiadka (1980), was used to analyze caddisfly larvae at the level of the entire material and particular types of water bodies.

$$
D=\frac{n_{i}}{N_{s}} \times 100 \%
$$

$\mathrm{D}$ - dominance of the species

$\mathrm{n}_{\mathrm{i}}$ - number of individuals of the species $i$

$\mathrm{N}$ - number of all individuals of all species

\begin{tabular}{|c|c|c|c|}
\hline Variable & Abbreviation & Mu & Ranges (Mean with SD) \\
\hline \multicolumn{4}{|c|}{$\begin{array}{l}\text { Landscape variables: characteristics of patches in buffer zones: CA, area of particular patches; L, distance of particular patches from the centre of } \\
\text { buffer zone }\end{array}$} \\
\hline \multirow{2}{*}{ Built-up areas } & CA (1) & ha & $1.54 \pm 2.84(0.00-8.15)$ \\
\hline & $\mathbf{L}(1)$ & $\mathrm{m}$ & $113.88 \pm 180.78(0.00-461.60)$ \\
\hline \multirow[t]{2}{*}{ Fields } & CA (7) & ha & $22.43 \pm 12.24(3.83-44.80)$ \\
\hline & $\mathrm{L}(7)$ & $\mathrm{m}$ & $2.07-452.92(361,88 \pm 135.21)$ \\
\hline \multirow[t]{2}{*}{ Meadows and pastures } & $\mathrm{CA}(9)$ & ha & $17.20 \pm 12.37(1.04-37.30)$ \\
\hline & $\mathrm{L}(9)$ & $\mathrm{m}$ & $319.02 \pm 122.56(2.25-433.90)$ \\
\hline \multirow[t]{2}{*}{ Broadleaf forests } & CA (11) & ha & $13.64 \pm 6.45(5.17-25.67)$ \\
\hline & L (11) & $\mathrm{m}$ & $278.02 \pm 110.48(2.68-372.89)$ \\
\hline \multirow[t]{2}{*}{ Mixed forests } & CA (13) & ha & $4.88 \pm 6.96(0.00-16.30)$ \\
\hline & $\mathrm{L}(13)$ & $\mathrm{m}$ & $96.11 \pm 137.16(0.00-378.65)$ \\
\hline \multirow[t]{2}{*}{ Willow thickets } & CA (15) & ha & $1.97 \pm 1.82(0.00-9.79)$ \\
\hline & L (15) & $\mathrm{m}$ & $262.63 \pm 145.90(0.00-486.03)$ \\
\hline \multirow[t]{2}{*}{ Swamps } & $\mathrm{CA}(16)$ & ha & $1.76 \pm 1.44(0.00-4.32)$ \\
\hline & $\mathrm{L}(16)$ & $\mathrm{m}$ & $271.93 \pm 195.17(0.00-456.25)$ \\
\hline \multirow[t]{2}{*}{ Watercourses } & CA (17) & ha & $1.34 \pm 0.87(0.19-2.87)$ \\
\hline & L (17) & $\mathrm{m}$ & $230.22 \pm 129.19(7.36-390.79)$ \\
\hline \multirow[t]{2}{*}{ Water bodies } & CA (18) & ha & $2.51 \pm 5.02(0.00-19.88)$ \\
\hline & L (18) & $\mathrm{m}$ & $217.74 \pm 201.59(0.00-464.64)$ \\
\hline \multicolumn{4}{|c|}{ Catchment variables: characteristic of catchments - a, area; d, distance from the river } \\
\hline Catchment & a cat & ha & $3621.1 \pm 3745.4(469.4-11065.1)$ \\
\hline Catchment area from the springs & a cat cum & ha & $20928.9 \pm 22428.7(459.4-60568.3)$ \\
\hline Forests & a forest & ha & $912.83 \pm 1415.31(37.72-4067.95)$ \\
\hline Meadows and pastures & a mead & ha & $622.0 \pm 610.6(50.86-1787.2)$ \\
\hline Fields & a field & ha & $1957.50 \pm 610.63(111.54-4813.03)$ \\
\hline Built-up & a build & ha & $69.64 \pm 48.61(6.96-14.14)$ \\
\hline Water bodies & a st water & ha & $22.18 \pm 25.97(1.63-78.82)$ \\
\hline Marshland & a marsh & ha & $8.47 \pm 11.01(0.00-31.16)$ \\
\hline Rivers & a river & ha & $1.91 \pm 1.92(0.00-5.35)$ \\
\hline Shrubs & a shrub & ha & $6.89 \pm 11.36(0.00-31.98)$ \\
\hline Wasteland & a wast & ha & $19.64 \pm 41.02(0.00-111.30)$ \\
\hline Length of catchment boundaries & 1 bord & $\mathrm{m}$ & $38625.98 \pm 24031.11(12405.64-83599.36)$ \\
\hline Roughness & $\mathrm{Ra}$ & - & $12.72 \pm 3.21(9.17-19.84)$ \\
\hline Contagion & $\mathbf{C}_{\mathbf{r}}$ & - & $2.01 \pm 0.23(1.62-2.36)$ \\
\hline River gradient & river fal & $\mathrm{m}$ & $1.9 \pm 1.7(0.1-4.8)$ \\
\hline Distance from source & d source & $\mathrm{m}$ & $25875 \pm 18695(2073-64380)$ \\
\hline Forests & d fores & $\mathrm{m}$ & $516.60 \pm 259.72(278.05-1166.76)$ \\
\hline Fields & $\mathrm{d}$ field & $\mathrm{m}$ & $627.47 \pm 181.91(406.41-912.15)$ \\
\hline Marshland & d marsh & $\mathrm{m}$ & $489.62 \pm 466.32(0.00-1186.32)$ \\
\hline Meadows and pastures & $\mathrm{d}$ mead & $\mathrm{m}$ & $537.88 \pm 296.13(206.70-1196.86)$ \\
\hline Shrubs & d shrub & $\mathrm{m}$ & $372.09 \pm 350.28(0.00-1073.18)$ \\
\hline Water bodies & d st water & $\mathrm{m}$ & $246.97 \pm 375.19(246.97-1553.53)$ \\
\hline Built-up & d build & $\mathrm{m}$ & $534.05 \pm 260.05(213.25-910.61)$ \\
\hline
\end{tabular}

Tab. 2. Continued from previous page. 
The Shannon index was used to calculate diversity and Buzas and Gibson's formula to calculate evenness of caddisflies in particular types of water bodies and in subcatchments.

$$
H^{\prime}=\sum_{i=1}^{s} p_{i} \ln p_{i}
$$

H'- diversity index

$\mathrm{S}$ - number of species (species richness)

$\mathrm{p}_{\mathrm{i}}$ - the ratio of the number of individuals of a given species to the total number ofindividuals of all species: $\frac{\mathbf{n}_{\mathbf{i}}}{\mathbf{N}}$

$\mathrm{n}_{\mathrm{i}}$ - number of individuals of the species $i$

$\mathrm{N}$ - number of all individuals of all species

$$
E=\frac{e^{H^{\prime}}}{S}
$$

E - evenness

$\mathrm{H}$ ' - diversity index of Shannon and Wiener

$\mathrm{S}$ - the number of species in the assemblage

The Bray-Curtis Index (BC) was used to calculate faunistic similarities between sites (habitat types) and subcatchments. Jaccard's formula (J) was implemented in calculating quantitative similarities within all water types in the river valley.

$$
B C_{i j}=1-\frac{2 C_{i j}}{S_{i}+S_{j}}
$$

$\mathrm{BC}_{\mathrm{ij}}-$ Bray-Curtis dissimilarity

$\mathrm{C}_{\mathrm{ij}}$ - the sum of the lesser values for only those species in common between both sites

$\mathrm{S}_{\mathrm{i}}, \mathrm{S}_{\mathrm{j}}$ - the total number of specimens counted at both sites

$$
\mathbf{J}=\frac{\mathbf{c}}{\mathbf{a}+\mathbf{b}-\mathbf{c}}
$$

$\mathrm{J}-$ Jaccard similarity coefficient

$\mathrm{C}$ - number of species common to (shared by) quadrats

$\mathrm{a}, \mathrm{b}$ - numbers of species unique to the first quadrat and to the second quadrat

Calculations and dendrograms of similarities were made in PAST 3.06 software (Hammer et al., 2001).

Multivariate ordinations were performed in Canoco 4.5 (ter Braak and Smilauer, 2002) to examine the relationships between caddisfly larvae assemblages and environmental parameters. In these analyses, we considered only individuals identified to species level. First Detrended Correspondence Analysis (DCA) was used to obtain the gradient length (SD). Since this was short $(<2$ $\mathrm{SD})$, we applied a linear species response model. Redundancy Analyses (RDA) were conducted including all species abundance data. As a large number of landscape variables (buffer zones and catchments) were correlated with each other, we eliminated all strongly correlated parameters. Finally, there was a total of 29 uncorrelated landscape parameters in the RDA (Tab. 2).
We used the Kruskal-Wallis test and Dunn's post-hoc test to find statistically significant differences in individual parameters and faunistic indices (number of taxa and specimen, Shannon index - H, Evenness index - E, Caddisfly Habitat Index - CHI) describing the caddisfly larvae assemblages between sub-catchments with similar types of land usage. We used Spearman's correlation coefficients to determine significant landscape variables in sub-catchments with similar types of land usage influencing the above-mentioned faunistic indices. Ranges for coefficients of correlation were according to Hinkle et al. (2003). All tests were conducted in Statistica 10.0. software.

\section{RESULTS}

\section{Environmental characteristics of the water bodies at different scales}

Particular types of water bodies in the Krąpiel River valley differ in physicochemical parameters of water and sediment properties (Tab. 3). The best oxygen conditions and the lowest values of nitrogen compounds were found in springs, sedge marshes and alder carrs. Phosphates were the lowest in oxbows. Average conductivity values varied from 111 in small pools to almost 280 in oxbows. Turbidity was the lowest in springs and highest in oxbows. Mean $\mathrm{pH}$ values ranged from 5.9 in sedge marshes to almost 7 in springs. The lowest average temperature was found in oxbows and small pools, the highest - in alder carrs. Sedge marshes, small pools and alder carrs were dominated by organic fraction of sediments, while in riverine marshes and oxbows mineral fraction prevailed. $60 \%$ of all sites studied was connected with main channel during flood in the spring. Over $68 \%$ of water bodies were filled with water only for one to five months during the year of the studies (Tab. 1). The Krapiel River itself is a typical lowland river with $0.204 \mathrm{~m}$ $\mathrm{s}^{-1}$ mean current, relatively low mean values of nutrients and mineral bottom with small amount of organic component. As for the river flowing through catchment dominated by croplands, mean conductivity of water is relatively low. However, taking into consideration the sub-catchment type grouping (MIX-FOR, MIX-AGR and AGR), water bodies situated within agricultural landscape had almost two times higher conductivity than sites located in sub-catchments dominated by forests (Supplementary Tab. 3). Sites studied within agricultural sub-catchments had also the worst oxygen conditions and the highest amount of nitrates. Insolation was comparable to this one measured in forest sub-catchments. Mineral fraction of sediments prevailed in agricultural and forest sub-catchments, organic fraction dominated in mixed landscape type with dominance of cropland. Additionally, Supplementary Tab. 2 shows mean values of physicochemical parameters of water and sediment properties measured in 13 sub-catchments. 


\section{Caddisfly larvae assemblages of the standing water bodies - general characteristics}

In the standing water bodies located in the valley of the Krapiel River 1005 caddisfly larvae were caught. In the material collected we found 35 species belonging to 10 families (Tab. 4). Dominant families were Limnephilidae (19 species, $79 \%$ of all specimens) and Hydropsychidae (5 species, $16 \%$ of specimens). The dominance structure of the entire material was very uneven: the eudominants class consisted of only two species, Limnephilus flavicornis and Hydropsyche incognita, and the dominants were represented by juvenile representatives of the genus Limnephilus and by Chaetopteryx villosa. The subdominants were more numerous and included Halesus tesselatus, Limnephilus lunatus, L. marmoratus, Glyphotaelius pellucidus, Limnephilus stigma and Hydropsyche pellucidula. The recedents class included as many as 29 taxa. The species composition of the three most dominant classes clearly indicates penetration into the water bodies by species (such as Limnephilus flavicornis, L. marmoratus, L. stigma) typical of standing waters (with extensive and rich in species helophyte zones) and species (such as Hydropsyche incognita, H. pellucidula, Chaetopteryx villosa, Halesus tesselatus) typical of flowing waters.

In comparison (Supplementary Tab. 1), the caddisfly larvae assemblages of the lentic floodplain habitats are qualitatively poorer than the lotic habitats of the Krapiel River by nearly half, and 8 times less abundant. However, some species were collected only in the lentic habitats (see also Tab. 4): Beraea maurus, B. pullata, (both only in springs), Psychomyia pusilla (only in oxbows), Stenophylax vibex (only in springs) and Trichostegia minor (only in pools). As many as 27 species were common to the floodplain water bodies and the river itself. More detailed analysis of faunistic similarities of caddisfly larvae in the standing water and river sites, taking into account current and marginal pool sub-habitats, showed that the river still constitutes a separate entity $(\mathrm{J}=61 \%, \mathrm{BC}=41 \%)$.

Quantitative faunistic similarities between types of standing water bodies were fairly low, ranging from $9 \%$ to $29 \%$ (Fig. 2), which indicates that the faunas of different types of water bodies are highly distinct. The most similar caddisfly larvae assemblages were noted for the small water bodies and the alder carrs: this similarity was the result of 5 common taxa (all representatives of the family Limnephilidae), of which the most numerous was Limnephilus flavicornis (256 ind.). Similarity of fauna between the alder carrs and the marshes was just $1 \%$ lower, with 3 common species of the genus Limnephilus, and again the most abundant was L. flavicornis (63 ind.).

Much higher similarities (up to $80 \%$ ) were noted when caddisfly larvae assemblages were compared between sub-catchments (Fig. 3). The highest similarities were found between agricultural catchments (K6 and K10) and forest catchments (K1 and K9). The upper part of the dendrogram contains agricultural catchments, including three that are solely agricultural, while the middle contains forest catchments (K1, K3 and K9), with similar species composition, and the lower part, with the exception of K2, again shows an assemblage typical of agricultural catch-

Tab. 3. Mean values of physicochemical parameters of water and sediment properties in the river and particular types of water bodies in the River Krąpiel valley.

\begin{tabular}{|c|c|c|c|c|c|c|c|}
\hline & $\mathrm{AC}$ & OX & PO & RM & SM & SP & River \\
\hline \multicolumn{8}{|l|}{ Water } \\
\hline $\mathrm{O} 2 \mathrm{mg} \mathrm{L}^{-1}$ & 5.53 & 5.15 & 4.71 & 4.13 & 5.55 & 6.07 & 7.91 \\
\hline BOD5 mg L ${ }^{-1}$ & 3.52 & 5.00 & 1.97 & 4.92 & 1.76 & 2.59 & 4.77 \\
\hline NH4 mg L ${ }^{-1}$ & 1.17 & 1.30 & 0.84 & 1.03 & 0.68 & 0.68 & 0.65 \\
\hline $\mathrm{NO} 3 \mathrm{mg} \mathrm{L}^{-1}$ & 0.55 & 1.33 & 0.60 & 1.09 & 0.93 & 1.14 & 2.69 \\
\hline PO4 mg L ${ }^{-1}$ & 0.48 & 0.33 & 0.45 & 0.66 & 0.79 & 0.56 & 0.34 \\
\hline Conductivity $\mu \mathrm{s} \mathrm{cm}^{-1}$ & 158.54 & 279.85 & 111.07 & 215.33 & 145.12 & 237.68 & 209 \\
\hline Turbidity $\mathrm{mg} \mathrm{L}^{-1}$ & 25.89 & 50.98 & 31.23 & 36.03 & 33.82 & 13.79 & 24.6 \\
\hline Hardness mg L ${ }^{-1}$ & 132.85 & 186.79 & 93.49 & 161.67 & 133.75 & 184.27 & 179.24 \\
\hline $\mathrm{pH}$ & 6.29 & 6.49 & 6.44 & 6.48 & 5.98 & 6.97 & 7.4 \\
\hline $\mathrm{Fe} \mathrm{mg} \mathrm{L}^{-1}$ & 0.10 & 0.09 & 0.21 & 0.18 & 0.09 & 0.23 & 0.13 \\
\hline Temperature ${ }^{\circ} \mathrm{C}$ & 16.25 & 13.76 & 13.22 & 15.81 & 14.57 & 15.35 & 15.5 \\
\hline Insolation $\%$ & 36.91 & 51.25 & 26.37 & 98.55 & 92.18 & 21.05 & 57 \\
\hline \multicolumn{8}{|l|}{ Sediments } \\
\hline Organic \% & 52.21 & 21.31 & 55.34 & 18.06 & 65.46 & 34.22 & 10.6 \\
\hline Mineral \% & 47.79 & 78.69 & 44.66 & 81.94 & 34.54 & 65.78 & 89.4 \\
\hline M (mean sediment grain size) & 0.87 & 1.38 & 1.66 & 0.70 & 0.01 & 0.99 & 1.3 \\
\hline W (sediment sorting) & 1.56 & 1.50 & 1.23 & 1.44 & 0.81 & 1.93 & 1.56 \\
\hline
\end{tabular}

OX, oxbows; RM, riverine marshes; PO, small water bodies (pools); SM, sedge marshes; AC, alder cars; SP, springs. 
ments. It is worth noting that the sub-catchments are not simply arranged in a linear manner, from the source to the mouth of the river.

\section{Functional groups of caddisfly larvae assemblages in standing water bodies}

Analysis of the current preferences of the Trichoptera fauna inhabiting all the water bodies of the Krapiel River valley showed that nearly half of the species were limnophiles (48\%). The contribution of the next two most abundant groups, rheo-limnophiles and rheophiles, was comparable (16\% and $17 \%$, respectively). Rheobionts accounted for $11 \%$, while limnobionts were the least abundant $(6 \%)$. The proportions of these groups in different types of water bodies were highly varied (Fig. 4). The most diverse fauna was noted in the oxbows. Limnophiles were clearly dominant in small water bodies and riverine marshes. The sedge marshes were characterized by fairly equal proportions of these three groups, all of which have

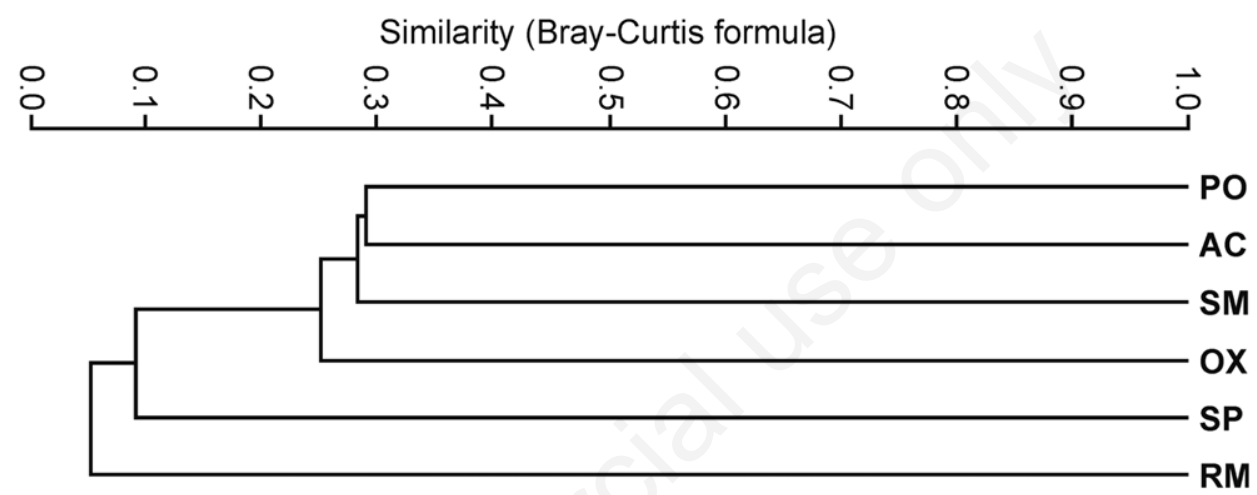

Fig. 2. Dendrogram of quantitative faunistic similarities between different types of standing water bodies in the Krąpiel River valley: OX, oxbows; RM, riverine marshes; PO, small water bodies (pools); SM, sedge marshes: AC, alder cars; SP, springs.

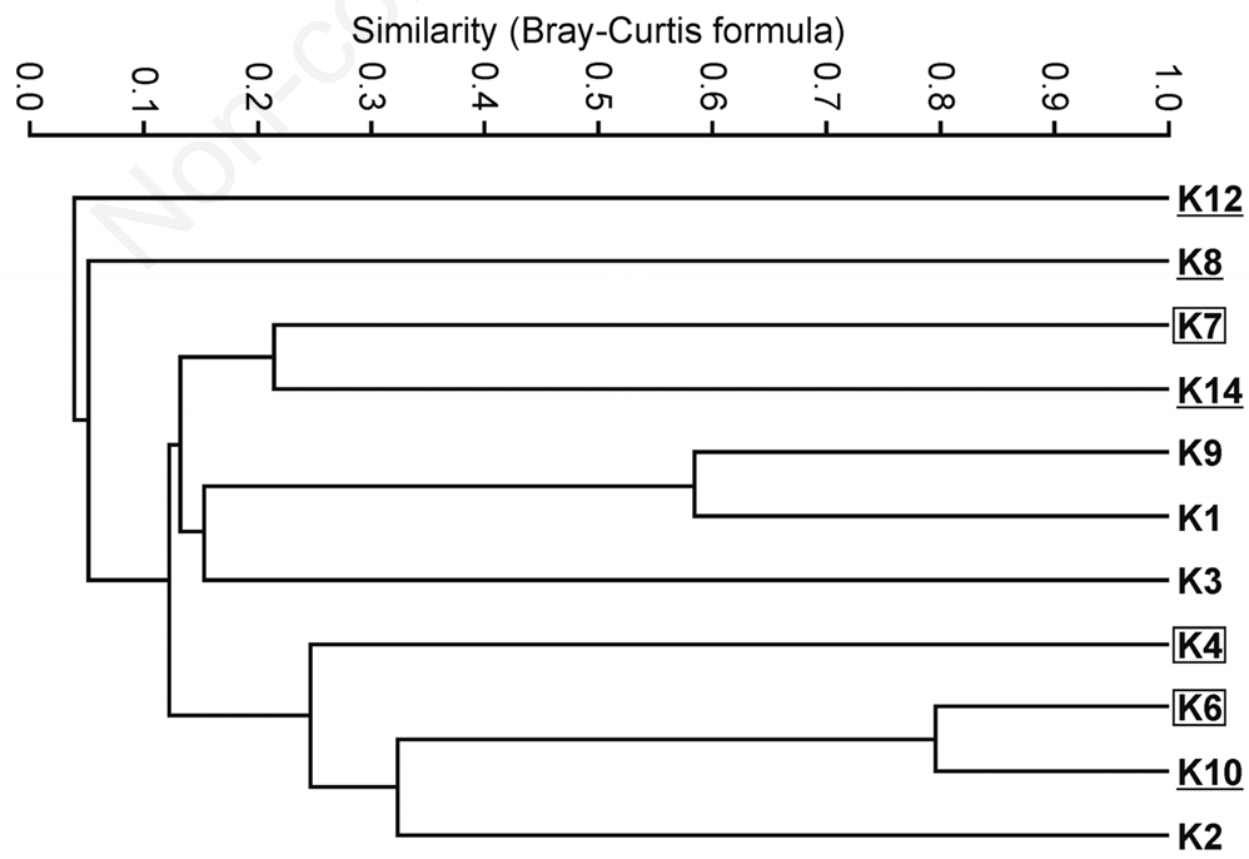

Fig. 3. Dendrogram of quantitative faunistic similarities between sub-catchments in the Krąpiel River valley (no underline, mixed subcatchment with forests; single underline, agricultural sub-catchment; in square, mixed sub-catchment with dominance of cropland). 
greater affinity for standing waters. In the springs, rheobionts accounted for as much as $70 \%$ of the fauna. The sequence of the water bodies according to habitat prefer- ences of fauna, from the most to the least associated with flowing water, was as follows: springs - oxbows - sedge marshes - alder carrs - small pools - riverine marshes.

Tab. 4. Trichoptera of standing waters in the River Krąpiel catchment provided as dominance structure of particular habitat types. Eudominants $(>10 \%)$ given in bold.

\begin{tabular}{|c|c|c|c|c|c|c|c|c|c|}
\hline No. & Taxon & Codes & OX & $\mathbf{R M}$ & PO & SM & $\mathrm{AC}$ & SP & $\Sigma$ \\
\hline 1. & Anabolia nervosa (Curt.) & Ana ner & 2.37 & 0.00 & 0.34 & 2.50 & 0.00 & 0.00 & 12 \\
\hline.- & Anabolia sp. & - & 0.53 & 0.00 & 0.00 & 0.00 & 0.00 & 0.00 & 2 \\
\hline 2. & Athripsodes albifrons (L.) & Ath alb & 0.79 & 0.00 & 0.00 & 0.00 & 0.00 & 0.00 & 3 \\
\hline 3. & Beraea maurus (Curt.) & Ber mau & 0.00 & 0.00 & 0.00 & 0.00 & 0.00 & 20.43 & 19 \\
\hline 4. & B. pullata (Curt.) & Ber pul & 0.00 & 0.00 & 0.00 & 0.00 & 0.00 & 1.08 & 1 \\
\hline 5. & Chaetopteryx villosa (Fabr.) & Cha vil & 4.22 & 0.00 & 0.00 & 0.00 & 0.00 & 51.61 & 64 \\
\hline 6. & Glyphotaelius pellucidus (Retz.) & Gly pel & 0.00 & 0.00 & 6.40 & 0.00 & 6.56 & 9.68 & 32 \\
\hline 7. & Halesus digitatus (Schr.) & Hal dig & 4.75 & 0.00 & 0.00 & 0.00 & 1.64 & 0.00 & 19 \\
\hline 8. & H. tesselatus (Ramb.) & Hal tes & 12.14 & 0.00 & 0.00 & 0.00 & 0.00 & 0.00 & 46 \\
\hline.- & Halesus sp. & - & 3.43 & 0.00 & 0.00 & 0.00 & 0.00 & 0.00 & 13 \\
\hline 9. & Holocentropus stagnalis (Alb.) & Hol sta & 0.00 & 0.00 & 0.67 & 0.00 & 0.00 & 0.00 & 2 \\
\hline 10. & H. angustipennis (Curt.) & Hyd ang & 0.53 & 0.00 & 0.00 & 0.00 & 0.00 & 0.00 & 2 \\
\hline 11. & H. incognita Pitsch & Hyd inc & 31.66 & 0.00 & 0.00 & 0.00 & 0.00 & 0.00 & 120 \\
\hline 12. & H. pellucidula (Curt.) & Hyd pel & 6.07 & 0.00 & 0.00 & 0.00 & 0.00 & 0.00 & 23 \\
\hline 13. & H. saxonica $\mathrm{McL}$. & Hyd sax & 0.26 & 0.00 & 0.00 & 0.00 & 0.00 & 0.00 & 1 \\
\hline 14. & H. siltalai Doehl. & Hyd sil & 3.43 & 0.00 & 0.00 & 0.00 & 0.00 & 0.00 & 13 \\
\hline- & Hydropsyche sp. (juv.) & - & 0.00 & 0.00 & 0.34 & 0.00 & 0.00 & 0.00 & 1 \\
\hline 15. & Ironoquia dubia (Steph.) & Iro dub & 0.79 & 0.00 & 0.00 & 0.00 & 0.00 & 0.00 & 3 \\
\hline 16. & Lepidostoma hirtum (Fabr.) & Lep hir & 0.53 & 0.00 & 0.00 & 0.00 & 0.00 & 0.00 & 2 \\
\hline 17. & Limnephilus auricula Curt. & Lim aur & 0.00 & 0.00 & 0.34 & 6.25 & 0.00 & 1.08 & 7 \\
\hline 18. & L. binotatus Curt. & Lim bin & 0.00 & 0.00 & 0.00 & 18.75 & 0.00 & 4.30 & 19 \\
\hline 19. & L. bipunctatus Curt. & Lim bip & 0.00 & 0.00 & 0.67 & 1.25 & 0.00 & 0.00 & 3 \\
\hline 20. & L. centralis Curt. & Lim cen & 0.00 & 0.00 & 0.00 & 3.75 & 0.00 & 0.00 & 3 \\
\hline 21. & L. flavicornis (Fabr.) & Lim fla & 20.32 & 4.21 & 73.06 & 17.50 & 63.93 & 1.08 & 352 \\
\hline 22. & L. griseus (L.) & Lim gri & 0.00 & 0.00 & 0.00 & 0.00 & 1.64 & 1.08 & 2 \\
\hline 23. & L. lunatus Curt. & Lim lun & 1.58 & 0.00 & 0.67 & 42.50 & 3.28 & 1.08 & 45 \\
\hline 24. & L. marmoratus Curt. & Lim mar & 0.00 & 0.00 & 11.45 & 0.00 & 1.64 & 0.00 & 35 \\
\hline 25. & L. nigriceps (Zett.) & Lim nig & 0.00 & 0.00 & 0.00 & 1.25 & 0.00 & 0.00 & 1 \\
\hline 26. & L. rhombicus (L.) & Lim rho & 0.53 & 0.00 & 0.00 & 0.00 & 11.48 & 0.00 & 9 \\
\hline 27. & L. stigma Curt. & Lim sti & 0.79 & 0.00 & 4.38 & 5.00 & 9.84 & 0.00 & 26 \\
\hline- & Limnephilus sp. (juv.) & - & 0.53 & 95.79 & 1.01 & 0.00 & 0.00 & 0.00 & 96 \\
\hline 28. & Oecetis furva (Ramb.) & Oec fur & 0.00 & 0.00 & 0.00 & 1.25 & 0.00 & 0.00 & 1 \\
\hline 29. & Plectrocnemia conspersa (Curt.) & Ple con & 0.26 & 0.00 & 0.00 & 0.00 & 0.00 & 0.00 & 1 \\
\hline 30. & Potamophylax nigricornis (Pict.) & Pot nig & 0.00 & 0.00 & 0.00 & 0.00 & 0.00 & 1.08 & 1 \\
\hline 31. & Psychomyia pusilla (Fabr.) & Psy pus & 0.26 & 0.00 & 0.00 & 0.00 & 0.00 & 0.00 & 1 \\
\hline 32. & Rhyacophila nubila (Zett.) & Rhy nub & 3.96 & 0.00 & 0.00 & 0.00 & 0.00 & 0.00 & 15 \\
\hline 33. & Sericostoma personatum (Spence) & Ser per & 0.26 & 0.00 & 0.00 & 0.00 & 0.00 & 0.00 & 1 \\
\hline 34. & Stenophylax vibex (Curt.) & Ste vib & 0.00 & 0.00 & 0.00 & 0.00 & 0.00 & 7.53 & 7 \\
\hline \multirow[t]{5}{*}{35.} & Trichostegia minor (Curt.) & Tri min & 0.00 & 0.00 & 0.67 & 0.00 & 0.00 & 0.00 & 2 \\
\hline & Number of taxa & & 23 & 2 & 12 & 10 & 8 & 11 & \\
\hline & Number of individuals & & 379 & 95 & 297 & 80 & 61 & 93 & \\
\hline & Shannon_H & & 2.22 & 0.17 & 1.03 & 1.69 & 1.26 & 1.51 & \\
\hline & Evenness & & 0.4 & 0.59 & 0.23 & 0.53 & 0.43 & 0.41 & \\
\hline
\end{tabular}




\section{Impact of catchment type on caddisfly larvae assemblages and Caddisfly Habitat Index}

A Kruskal-Wallis test comparing the values of five ecological indices at the level of samples describing the caddisfly larvae assemblages in sub-catchments with different types of land use (agricultural, mixed agricultural and mixed forest) showed no statistically significant differences.

Spearman's correlation coefficient was used to test which of the 41 landscape parameters describing the catchment and patches of buffer zones most strongly influenced the caddisfly larvae assemblages in the three types of sub-catchment. For five faunistic metrics no correlation was found in any catchment type; correlations were found only for functional groups. The fewest moderate correlations were found for the forest catchments only $5.3 \%$, while for the mixed-agricultural catchments $7.5 \%$ of correlations were moderate. In contrast, in the case of solely agricultural catchments $27 \%$ of correlations were statistically significant, and these were moderate and strong correlations. Tab. 5 presents the most important of these: two each for catchment parameters and buffer zones, if found. Catchment parameters (more distant) were most important for functional groups of caddisfly larvae in the forested areas, and buffer zone parameters (closer) in the agricultural areas (mixed and solely agricultural). Among parameters describing catchments, the total surface area of the river and swamps were most important for different functional groups. Buffer zone parameters in the agricultural and forest catchments had a clear differentiating character: for example, surface areas and distances from densely built-up areas were important for functional groups of agricultural areas, while in forested areas parameters associated with surface area and distance from broadleaf forests were significant for three different functional groups. In agricultural sub-catchments, the strongest correlations determining abundances of species constituting the paleopotamon were noted.

The CHI values for different sampling sites varied from 1.5 to 4.8. All ranges for the index, from habitat types $\mathrm{H} 1$ to $\mathrm{H} 5$, were represented in the water bodies of the river valley, with the most sites $(50 \%)$ in category $\mathrm{H} 4$, followed by $\mathrm{H} 3$ (25\%), H2 (11\%), and $\mathrm{H} 1$ and $\mathrm{H} 5$, with $7 \%$ each. Agricultural sub-catchments reached the lowest values of CHI (MIX-AGR - 2.8, AGR - 3.08), while the forest sub-catchment - the highest (MIX-FOR - 3.64).

\section{Caddisfly larvae assemblages and habitat factors - physicochemical water parameters and structural factors of water bodies}

The results of direct RDA for distribution of caddisfly larvae assemblages depending on 11 physicochemical water parameters showed that the variables used in the ordination explain $22.7 \%$ of the total species variance (Fig. $5 \mathrm{~A})$. The first two eigenvalues represented $13 \%$ of the variance in the species abundance data and $56 \%$ of the variance in the species-environment relationship. The results of step-wise selection of the environmental variables showed that only one variable, $\mathrm{pH}$, was statistically significant (conditional importance $\lambda \mathrm{a}=0.07, \mathrm{~F}=4.75$, $\mathrm{P}=0.002$ ). Along the gradient of the first axis the highest negative correlation between the variables used and the

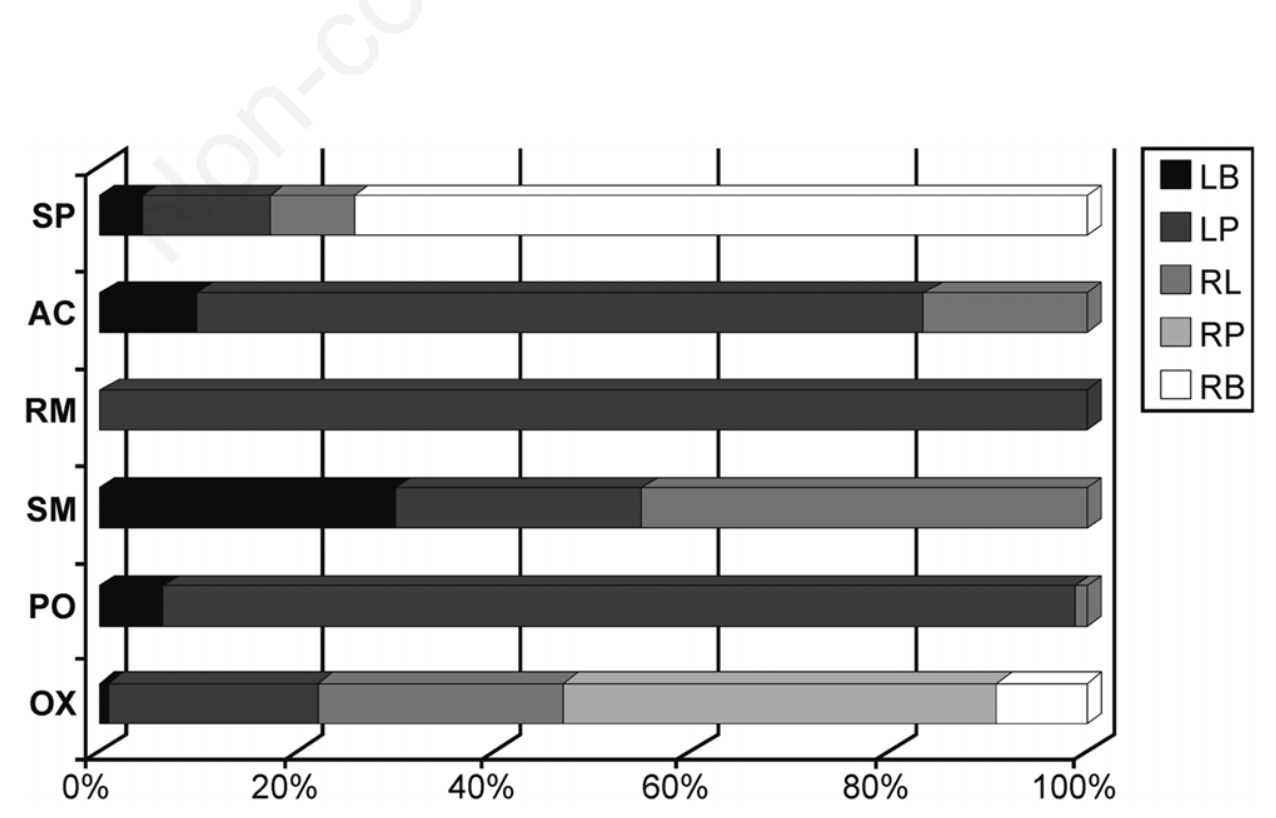

Fig. 4. Percentage contribution of functional groups of caddisflies based on current preferences (LB, limnobionts; LP, limnophiles; RL, rheo-limnophiles; RP, rheophiles; RB, rheobionts) in different types of standing water bodies in the Krąpiel River valley. OX, oxbows; $\mathrm{RM}$, riverine marshes; PO, small water bodies (pools); SM, sedge marshes; AC, alder cars; SP, springs. 
distribution of species was in fact noted for $\mathrm{pH}(\mathrm{r}=-0.64)$. $\mathrm{Fe}$ ions are the defining parameter in the case of the second axis, nitrates for the third and temperature for the fourth, although these relationships were not statistically significant. The species most strongly positively correlated with $\mathrm{pH}$ were Limnephilus auricula, L. stigma, $L$. marmoratus, L. lunatus, Stenophylax vibex and Chaetopteryx villosa.

The RDA considering structural parameters of water bodies showed that 8 variables explained $14 \%$ of the total Trichoptera species variance (Fig. 5B). The first two eigenvalues on the biplot represented $8.4 \%$ of the variance in the species abundance data and $60 \%$ of the variance in the species-environment relationship. The results of forward selection showed that 3 variables, i.e. sediment grain size (M) (conditional importance $\lambda \mathrm{a}=0.03, \mathrm{~F}=1.83$, $\mathrm{P}=0.003$ ), insolation (INSO) (conditional importance $\lambda \mathrm{a}=0.02, \mathrm{~F}=1.42, \mathrm{P}=0.003$ ), and plant cover (plants) (conditional importance $\lambda \mathrm{a}=0.03, \mathrm{~F}=2.12, \mathrm{P}=0.024)$, statistically significantly explained the range of total variance in occurrence of species. The first ordination axis is defined by two insignificant variables: the proportions of mineral and organic sediment. The second axis is defined by sediment grain size $(\mathrm{r}=0.41)$, the third by insolation $(\mathrm{r}=0.32)$, and the fourth by sediment sorting. Trichostegia minor, Holocentropus stagnalis, Limnephilus flavicornis and $L$. marmoratus displayed preferences for the largest sediment grains and at the same time preferred sites with less plant cover. Limnephilus lunatus showed the most pronounced affinity for open, insolated sites.

\section{Caddisfly larvae assemblages and habitat variables - landscape parameters in buffer zones and sub-catchments}

Ten variables were used in the RDA for the dependence of caddisfly distribution on landscape metrics (indices) in buffer zones (Fig. 6A). These variables explained $15 \%$ of the total variance in the Trichoptera of the water bodies. The first two eigenvalues represented $8.4 \%$ of the variance in the species abundance data and $55 \%$ of the variance of the species-environment relationship. Of these parameters, only the Shannon evenness index (SEI - conditional importance $\lambda \mathrm{a}=0.03, \mathrm{~F}=2.09, \mathrm{P}=0.004$ ) and the total edge length of patches (TE - conditional importance $\lambda \mathrm{a}=0.02, \mathrm{~F}=1.61, \mathrm{P}=0.014$ ) were statistically significant. The first ordination axis is defined by the parameter SEI $(\mathrm{r}=-0.48)$, and the second by MTE - mean edge length $(\mathrm{r}=0.33)$.

The RDA for the variables of different patches in the buffer zones following prior reduction of data showed that these variables explained $17 \%$ of the total variance in the Trichoptera of the sampling sites (Fig. 6B). The first two eigenvalues represented $9.2 \%$ of the variance in the species abundance data and $54 \%$ of the variance of the species-environment relationship. The first axis was de-

Tab. 5. Spearman's rank correlation coefficients between caddisflies (FG - functional groups) and landscape parameters (defining catchments and buffer zones) in three main catchment types with different management.

\begin{tabular}{llccc} 
FG & Catchment: MIX-FOR & & \\
LP & a marsh & -0.487632 & CA (11) & 0.45796 \\
& d field & 0.45796 & CA (13) & 0.506188 \\
\hline PRP & a river & 0.471568 & L (13) & 0.445220 \\
\hline PAP & a marsh & -0.598456 & CA (13) & 0.571636 \\
& d st water & 0.54996 & L (15) & 0.46939 \\
& Catchment: MIX-AGR & & & 0.671485 \\
LB & d shrub & -0.64670 & CA (1) & 0.671485 \\
& d fores & -0.64670 & L (1) & \\
& Catchment: AGR & & L (9) & 0.604423 \\
LP & a marsh & 0.604423 & L (16) & -0.617952 \\
& a river & -0.53198 & CA (1) & 0.659973 \\
\hline RB & a marsh & -0.622228 & L (1) & 0.659973 \\
& a river & 0.62223 & CA (1) & 0.433904 \\
\hline RP & & & L (1) & 0.433904 \\
& & & CA (1) & 0.513488 \\
\hline PLP & a marsh & L (1) & 0.513488 \\
& a river & -0.484122 & CA (1) & -0.803040 \\
\hline PAP & a marsh & 0.48412 & L (1) & -0.803040 \\
& a river & 0.784199 & -0.73003 &
\end{tabular}

LB, limnobionts; LP, limnophiles; $R B$, rheobionts; RP, rheophiles; PRP, parapotamon; PAP, paleopotamon; PLP, plesiopotamon. For explanation of abbreviations of variables see Tab. 2. 


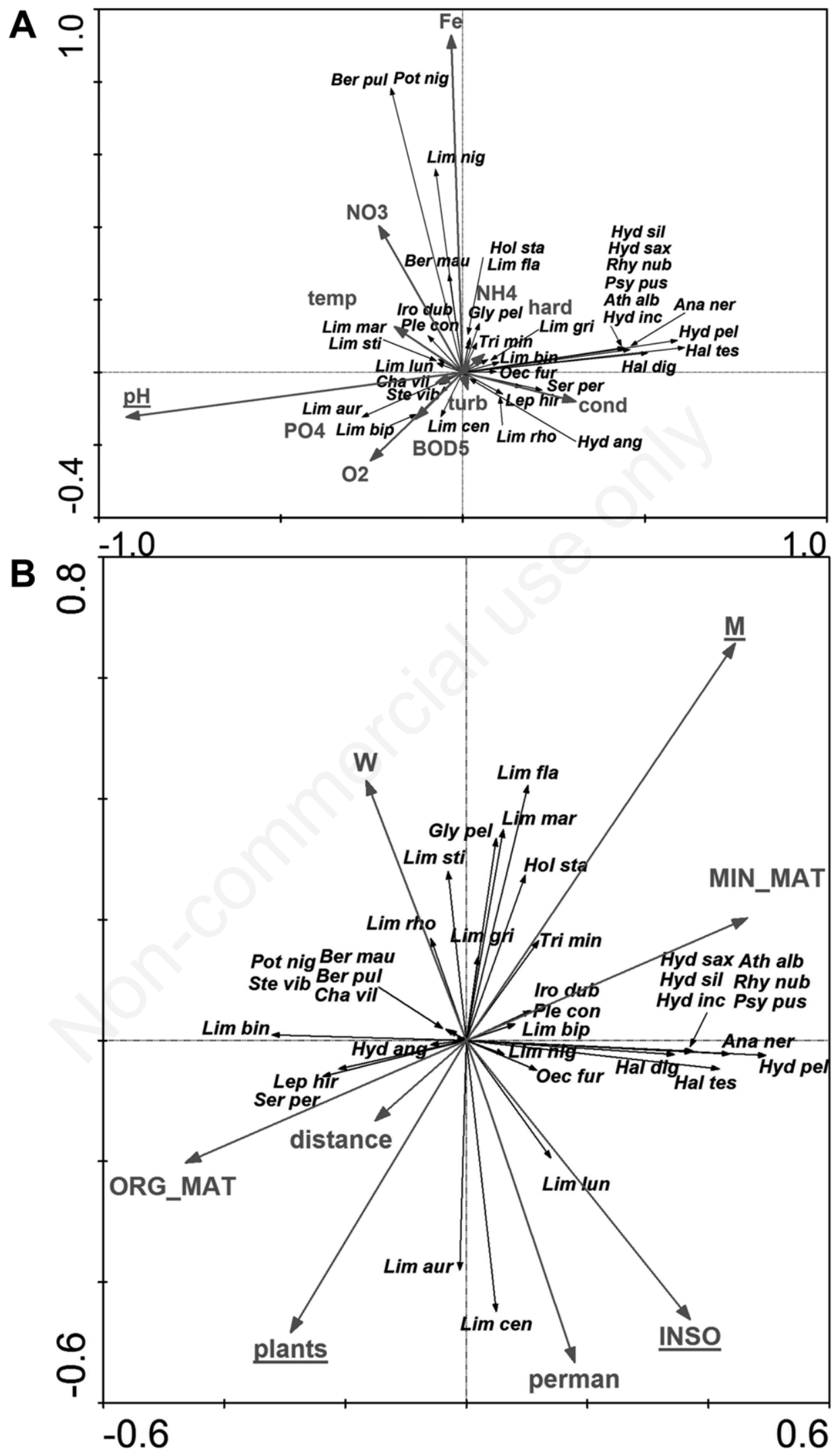

Fig. 5. RDA biplots showing relationships between caddisfly species and physicochemical (A) and structural (B) factors of water bodies of the Krąpiel River valley. Statistically significant parameters are underlined. See Tab. 2 and 3 for codes and abbreviations. 


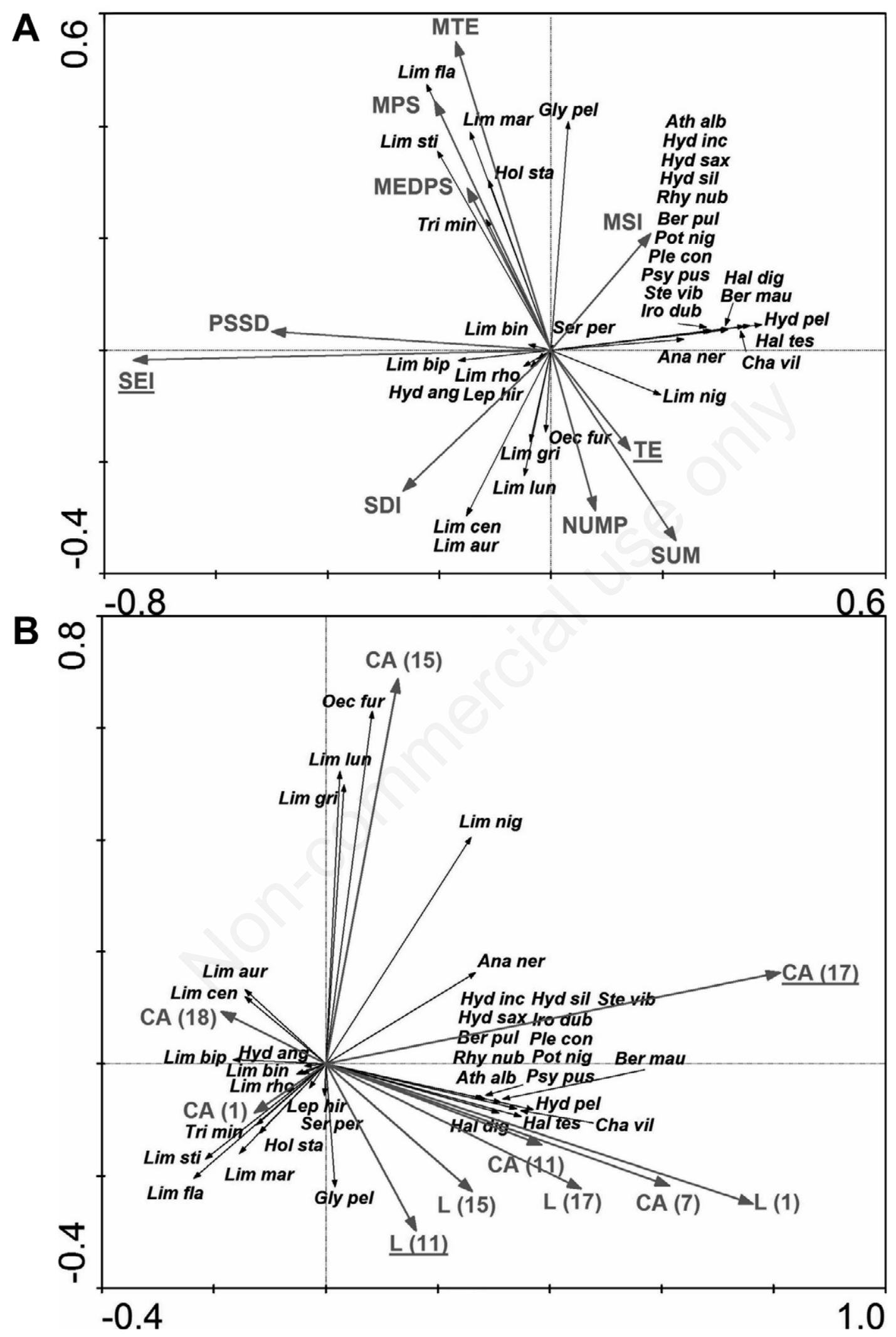

Fig. 6. RDA biplots showing relationships between caddisfly species and landscape metrics (indices) (A) and patch characteristics (B) in buffer zones of water bodies of the Krąpiel River valley. Statistically significant parameters are underlined. See Tab. 2 and 3 for codes and abbreviations. 
fined by the total surface area of the watercourses $\mathrm{CA}(17)(\mathrm{r}=0.53)$ and the second by the total area of willow thickets - $\mathrm{CA}(15)(\mathrm{r}=0.52)$. Step-wise analysis revealed that two parameters were statistically significant: the total surface area of the watercourses - CA(17) (conditional importance $\lambda \mathrm{a}=0.04, \mathrm{~F}=2.47, \mathrm{P}=0.002$ ) and distance from broadleaf forests - L(11) (conditional importance $\lambda \mathrm{a}=0.02, \mathrm{~F}=1.80, \mathrm{P}=0.034$ ). Anabolia nervosa and a large group of rheophilic and rheobiontic species were most associated with the total surface area of the watercourses, and Glyphotaelius pellucidus, Lepidostoma hirtum and Sericostoma personatum with the distance from broadleaf forests.

Nine variables were used in the RDA for the effect of parameters of the entire catchment on caddisfly distribution (Fig. 7). These explained $15 \%$ of the total variance in Trichoptera. The first two eigenvalues represented $8.4 \%$ of the variance in the species abundance data and $56 \%$ of the variance in the species-environment relationship. The first axis was defined by the surface area of the river (a river) $(\mathrm{r}=0.55)$ and the second by distance from standing waters ( $\mathrm{d}$ st water) $(\mathrm{r}=0.16)$. Only the surface area of the river - a river (conditional importance $\lambda \mathrm{a}=0.04$, $\mathrm{F}=2.68, \mathrm{P}=0.002$ ) and distance from standing water bod- ies $-\mathrm{d}$ st water (conditional importance $\lambda \mathrm{a}=0.06, \mathrm{~F}=1.71$, $\mathrm{P}=0.034$ ) were statistically significant.

The above analyses indicate that physicochemical water parameters explained the highest percentage of Trichoptera variance in the water bodies (Fig. 8). The remaining groups of parameters were of lower, and more importantly, very similar significance. These values in general are not very high. In each group, there were one to three statistically significant variables. Various landscape parameters taken into account in the analyses performed at the level of the catchment and buffer zones yielded very similar results, both in the case of closer factors (buffer zones) and more distant ones (the catchment).

\section{DISCUSSION}

The presented results clearly demonstrate that caddisfly larvae show diverse responses at different levels of their organization (as illustrated by biodiversity indexes, species assemblages and functional groups) and at different scales of impact of environmental factors (Fig. 8). They can be considered a representative and useful group contributing new and important information on the func-

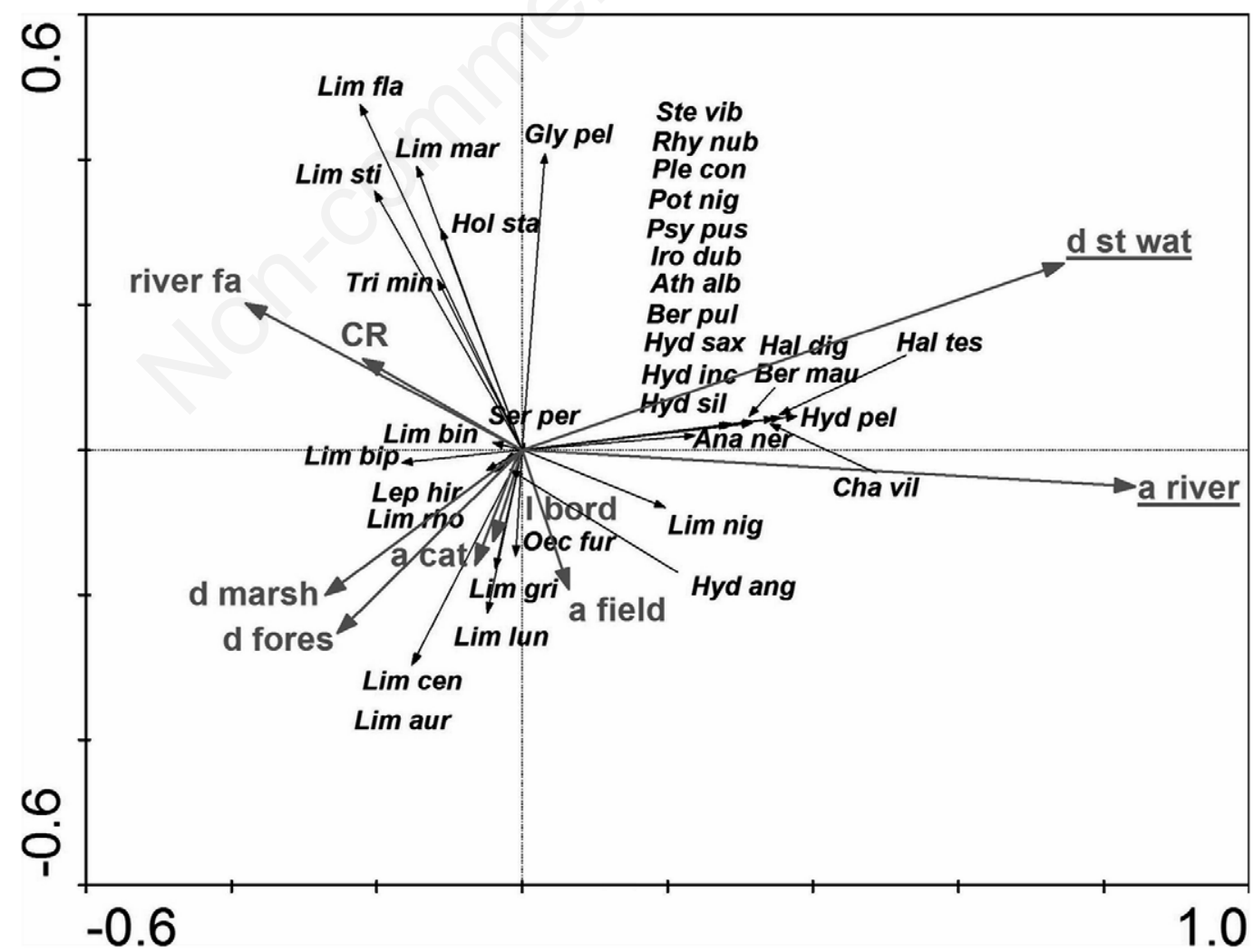

Fig. 7. RDA biplot showing relationships between caddisfly species and catchment characteristics of the Krąpiel River. Statistically significant parameters are underlined. See Tab. 2 and 3 for codes and abbreviations. 
tioning and management of standing waters within riverfloodplain systems (see also Van den Brink et al., 2013a; 2013b). Our results also demonstrate that caddisfly larvae assemblages are shaped either by habitat features (physicochemical parameters as well as structural parameters of water bodies) or landscape features (different catchment characteristics), which corresponds with the results obtained by Bonada et al. (2005) for caddisflies in Mediterranean river basins. Although the percentages of variance explained by the three different sets of variables is low and very similar, direct, physicochemical factors, especially $\mathrm{pH}$, proved to be the most significant for caddisfly larvae assemblages in the catchment water bodies. Similar results were obtained by Heino et al. (2008), who analyzed indices describing stream macroinvertebrates in Finland and found that here too landscape/catchment variables had limited value and explained rather weak variability. The results of research based solely on caddisfly larvae are also very similar to our own: in Latvia Skuja and Spungisis (2010) found that physicochemical parameters played a crucial role in explaining caddisfly variabil- ity ( $16 \%$ maximum) in comparison to regional factors, of which only catchment size was important. In the USA, Galbraith et al. (2008) discovered that local (corresponding to our physicochemical and structural features) and regional variables explained $28.9 \%$ and $22.4 \%$, respectively. In Serbia, Savić et al. (2013) reported that chemical and physical variables were responsible for over $40 \%$ of the variation, while spatial variables explained $12.4 \%$. In the catchment of the Guadiamar River in Spain, Ruiz-García et al. (2012) also detected low values of variability (6$13.3 \%$ ) explained by different sets of environmental variables, but found hydrological and topographical parameters to be more important than physicochemical ones. According to Johnson and Host (2010), different results between studies might reflect differences in the size of the study region or the level (and possibly type) of disturbance. The spatial pattern of land cover is possibly less important for smaller watersheds, while for larger areas land cover proportions are more important.

At the local level (water body, river bed structure), $\mathrm{pH}$, sediment grain size, insolation and aquatic macrophytes

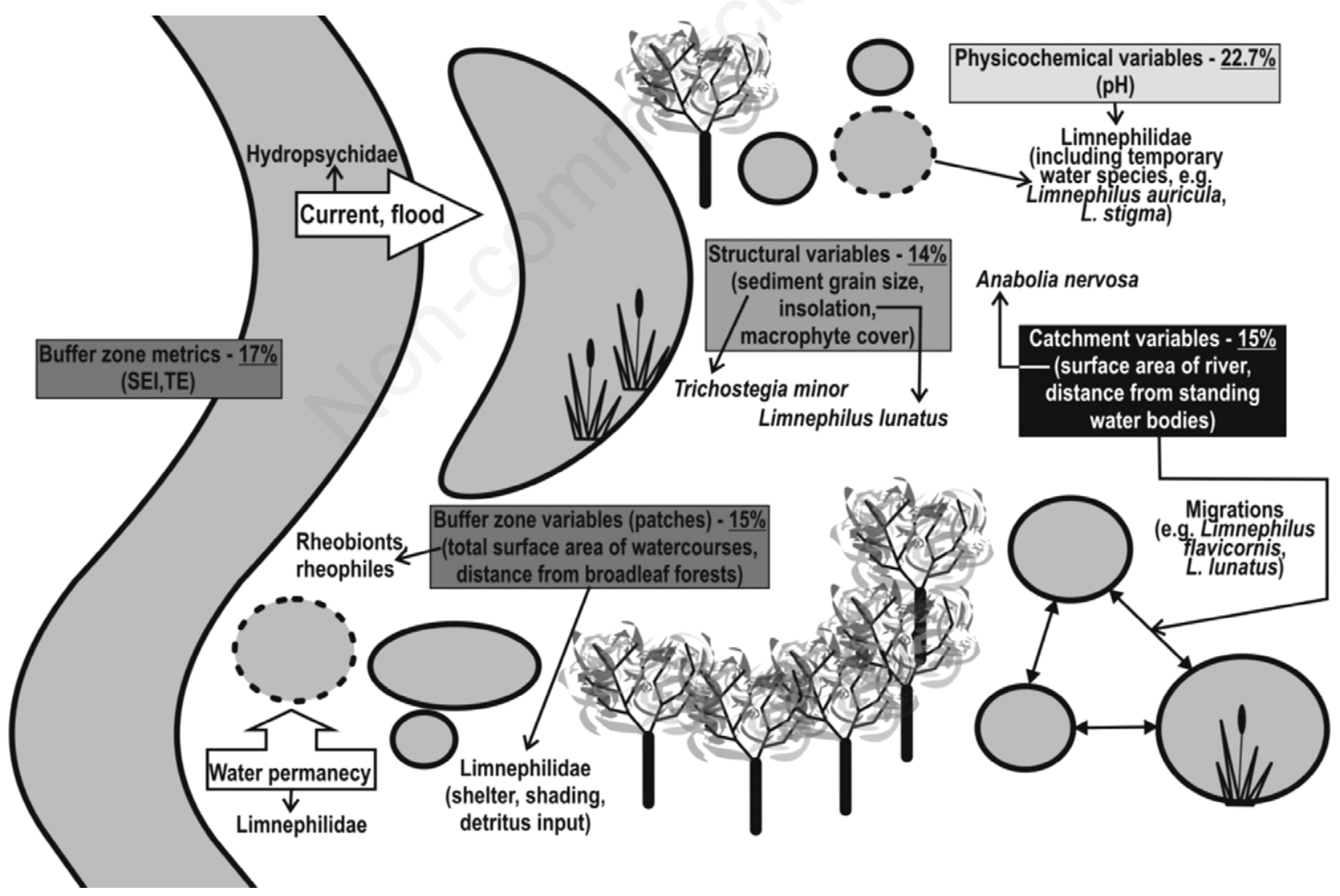

Fig. 8. Variables influencing caddisfly larvae distribution at different spatial levels in standing waters in the Krąpiel River valley. Spatial levels indicated by colour of the box: from light gray (lowest level) to black (highest level). Total variance (\%) and significant variables $(\mathrm{P}<0.005)$ are given in the boxes. 
proved significant for caddisflies. The importance of these variables for caddisfly larvae, has been demonstrated by many studies. Heino (2000), for example, found $\mathrm{pH}$, the presence and abundance of aquatic macrophytes, and as substratum particle size as significant for lentic macroinvertebrate assemblages, including caddisfly larvae. Savić et al. (2013) indicated $\mathrm{pH}$ as a statistically significant variable for the spatial distribution of caddisfly larvae. In comparison to small rivers in Poland like the Krapiel, standing waters have a wider $\mathrm{pH}$ spectrum; in our study, it varied from 2.1 to 8.3. Although low $\mathrm{pH}$ is generally regarded as unfavorable for most invertebrates, some caddisfly species are adapted to acidity, especially those inhabiting temporary waters (Wallace, 1991; Czachorowski, 1998). This matches with our results: such species, like Limnephilus auricula, L. griseus, L. marmoratus and L. stigma, which are regarded as acidophilous or acidotolerant species (Wallace, 1991; Czachorowski, 1998; Graf et al. 2008), were commonly found in alder carrs and sedge marshes ( $\mathrm{pH}$ ranges 5-7.86 and 4,4-8.3, respectively) during our study. However, a relation with $\mathrm{pH}$ may be indirect since predators like fish and amphibians may be absent in those waters. Water permanency without the reference to $\mathrm{pH}$ is another key factor determining species composition of caddisflies. Since almost $70 \%$ of all sites is temporary (alder carrs, the majority of small pools, riverine marshes, sedge marshes and springs), the contribution of the species adapted to drought is significance in the whole material. Species like Limnephilus auricula, L. binotatus, L. bipunctatus, L. centralis, L. griseus, L. stigma, Stenophyax vibex and Trichostegia minor, occurring in different types of waters in the study area, are recognized inhabitants of temporary waters (Wallace, 1991; Graf et al. 2008; Tachet et al. 2010).

At the higher level (landscape, catchment), for catchment and patch features in the buffer zones, the key parameters are clearly seen to be the surface areas of watercourses and the river, distance from standing waters and distance from broadleaf forests. The first three variables may highlight the importance of hydrological connectivity for caddisflies through formation of paths of dispersal and migration. This may also be confirmed by the high species similarity of the fauna of the river itself and the water bodies studied, as well as the large share of rheobionts, rheophiles and rheo-limnophiles (43\%) in the material. Worth mentioning is the high number of Hydropsychidae larvae collected in the oxbows. This caddisfly family depends on current velocity, however, of 11 oxbows studied, only one (sub-catchment K10) is permanently connected at one end with main channel. Hydropsychidae larvae were found only in two oxbows in sub-catchment K12 from May to July. The penetration of the larvae obviously occurred via flood shortly before sampling. The structure of current preferences of caddisfly larvae in the particular types of water bodies indicates that different functional groups are supported by different groups of habitats. For example, the occurrence of rheobionts, like Beraea maurus and B. pullata, is conditioned only by the presence of helocrenes. Spring and oxbows, habitats influenced by flood and current factor, are the most important in maintaining the highest diversity of functional groups of caddisfly larvae. Alder carrs, small pools and sedge marshes, affected by drought the most, provide the conditions for three functional groups each. River marshes are of minor significance in this matter. In general, some species representing different functional groups are found in different types of habitats, which confirms their dispersion abilities via water and air and highlights the importance of hydrological connectivity within the river valley (Fig. 8).

Variables solely associated with the water bodies best explain the variation at the largest (catchment) scale. The presence of broadleaf forests, may be significant for caddisflies in two ways. On the one hand their presence conditions the influx of organic matter, which is particularly important for shredder limnephilids, such as Limnephilus flavicornis, L. lunatus, L. marmoratus, L. stigma, Glyphotaelius pellucidus and Halesus tesselatus, whose percentage contribution in our material was significant. This was also emphasised by Arscott et al. (2003), who investigated caddisfly larvae assemblages of two headwater floodplains in Italy. The significance of broadleaf forests for aquatic invertebrates as an environmental factor has also been pointed out by Heino (2000), Mykrä et al. (2004) and Cortes et al. (2011). Kusch (2015) also emphasized that many caddisfly species have shown characteristic patterns in relation to this variable. On the other hand, dense forest patches may become a barrier for many adult caddisflies, and it should be emphasized that the forest parameter was significant only for the buffer zones level $(0.5$ $\mathrm{km}$ radius from the water body), while for the entire catchment no such relationship was found. In the buffer zones, two shape and edge metrics also proved significant for caddisflies: the Shannon evenness index and total edge length of patches. These indices can be directly applied to the mosaic concept (Duelli, 1997), according to which a larger number of patches and more border areas (ecotones) provide more niches to inhabit. In this light a higher SEI can create a greater probability that caddisfly species will colonize a patch with suitable conditions and thereby aid the dispersion mentioned above. Interestingly, no direct relationship was noted between caddisfly larvae assemblages and the surface area of the water bodies themselves or the sub-catchments, despite the fact that according to the concept of habitat islands this factor explains numerous distribution patterns (Heino, 2000). The arrangement of diverse patches (expressed as SEI) seems 
to be more important for Trichoptera than direct area measures (such as MPS, MDPS or NUMP). All the above data and the percentages of total variance in the various RDA analyses indicate that for Trichoptera assemblages the variables from each group are significant, from the habitat scale to the catchment scale. Many authors confirm that it is difficult to single out the most relevant set of drivers of one type shaping assemblages of invertebrates (Cortes et al., 2011), including caddisflies (Galbraith et al., 2008; Ruiz-García et al., 2012). Moreover, according to Allan (2004), covariation between natural and anthropogenic factors makes interpretation of the data more difficult.

Analysis of the effect of the three types of sub-catchment use on caddisfly larvae assemblages, based on diversity metrics analyzed together with characteristics of catchments and patches in buffer zones, did not yield clear results. To some extent, this may be caused by the fact that the types of water bodies are not equally distributed over the sub-catchments. However, variables considered separately for these sub-catchments showed significant correlations with some functional groups. Heino et al. (2008) reported that different faunal components may show different responses. At this level, we can see that each of the functional group can be dependent on different parameters and the most important (differentiating) factors can be distinguished for a forest or agricultural catchment. Our results are again consistent with those reported by Heino (2000) regarding lentic macroinvertebrates in the standing waters of Finland. The caddisfly larvae species composition in catchments with different usage types is also not accidental (Fig. 3), as the faunistic similarity between sub-catchments attained high values, and the analysis indicated specific groups corresponding to each type of sub-catchment. Forested areas were very distinct, clearly dominated by representatives of the genus Limnephilus, both qualitatively and quantitatively; only L. rhombicus was absent here. Thus, the significant correlations in the buffer zones with such parameters as broadleaf forests, mixed forests and willow thickets are unsurprising. Species of the genus Limnephilus are dependent on availability of coarse detritus from plant material in the water (Graf et al., 2008), which may come from trees and shrubs. Detritus originating in riparian vegetation (aquatic-based detritus) may also play a role; our results showed that macrophytes was significant in the analysis of structural variables for all caddisfly species recorded (Fig. 5B). The caddisfly faunas of agricultural and forest sub-catchments were clearly distinct, but this did not translate to the anticipated faunistic pattern induced by the land use gradient, in which higher correlation strength or higher faunistic indices would be typical of a more natural landscape (forest) than a modified one (agrocenosis), as claimed by Arscott et al. (2003), Zhang et al. (2012) or Kusch (2015). What is more interesting, such a pattern was observed in the case of the physicochemical variables considered in our data and in general in determination of water quality in Poland (Supplementary Tab. 3); these parameters, markedly higher in the agricultural sub-catchments, indicate that agricultural practices (such as fertilization) differentiate water quality in the entire catchment.

The caddisfly larvae diversity of the water bodies at the level of sub-catchments was not determined by water quality, as the species of the agricultural sub-catchments proved to be less sensitive than might be expected, which is in contradiction with numerous studies on the caddisflies of agricultural areas (Camargo et al., 2004; Gombeer el al., 2011). For comparison, Brand and Miserendino (2011) found the highest caddisfly larvae densities in a catchment with pastureland rather than in native forests. Perhaps for insects with high mobility an agricultural or partially agricultural catchment may be beneficial in that there are fewer barriers during migration, which is consistent with the assertion by Duelli (1997) that in agricultural areas mobility or fragmentation and isolation is not a limiting factor for animals. In general, differing results of research of this type may be linked to the fact that analysis based on only one scale (in this case land use) can lead to misleading interpretations (Ligeiro et al., 2013), whereas caddisflies are influenced by many other factors, including some of which were not the subject of our study, such as species interactions or life history strategies (Johnson and Host, 2010). Our atypical results, however, are more interesting in that the analysis of faunistic similarities at the level of water body types revealed that they were highly distinct. Comparable results were obtained in the case of functional groups analyzed at this level; the fauna of the water bodies showed no pattern induced by a given factor, such as size or permanence. Similar results for 21 lentic water bodies in Finland were obtained by Heino (2000). The land use factor modifying the catchment of a river is more significant (differentiating) for the studied caddisfly larvae than typology or the origin of water bodies, and results based on species and functional groups (correlations) can in this case be considered to be more meaningful. Faunistic metrics seem better suited to describing components of biological diversity for particular types of water bodies. Another important factor influencing the character of fauna is neighborhood dispersal processes; however, the factor of the proximity of particular sub-catchments also proved to be less important in our case.

According to Johnson and Host (2010), the influence of landscape variables on biotic assemblages is best and most accurately expressed in environments where we are not dealing with severe and widespread disturbances. As mentioned above, the differentiating character of catch- 
ment land use in the case of caddisflies was unclear. Another tool for assessing the state of the floodplain of a river is the Caddisfly Habitat Index, which emphasizes riverine connectivity and integrity. According to Ward (1998), the riverine ecosystem should be considered in four dimensions, including lateral connections and temporal dynamics. When we consider the distribution and values of this index, our results show that the entire floodplain system studied is in category II (good), in which species assemblages slightly deviate from type-specific reference conditions (Chovanec et al., 2005). At the same time, sites representing $\mathrm{H} 3$ and $\mathrm{H} 4$ habitats are dominant here, and the mean $\mathrm{CHI}$ value is 3.21 , which indicates a situation in which connectivity is fairly moderately restricted by human activity (Waringer and Graf, 2002). In general, the dynamics of the water bodies studied can be said to be disturbed to a moderate or even small degree, and caddisflies colonize water bodies according to their preferences without significant impediments.

The case of the floodplain system of the River Krapiel shows that caddisflies are well suited for assessment of ecological status and lateral connectivity even in relatively small lowland catchments. Moreover, research on standing water bodies in river floodplains has provided interesting and meaningful results as demonstrated by Van den Brink et al. (2013a), who studied a hydrological connectivity gradient in river-floodplain habitats in the Netherlands. This is the first study of this type in Poland to confirm that caddisfly larvae are good indicators of largescale processes and phenomena and can be useful as a single group for studying riverine systems or selected elements of them. Different levels of organization of these insects (species, faunistic indices, etc.) should be taken account here, as their response to different factors or phenomena is highly varied.

\section{CONCLUSIONS}

Caddisflies are aquatic insects responding to different environmental factors or disturbances (Goretti et al., 1995; Brand and Miserendino, 2011; Van den Brink et al., 2013a, 2013b; Kalaninová et al., 2014). Still, their responses at different spatial scales, especially in standing waters, are relatively poorly understood. Our studies conducted within varied water bodies of a lowland river valley revealed that physicochemical parameters $(\mathrm{pH}$ and probably also the water temporality) of the water bodies were indeed found to be one of the main driving factors of the caddisfly larvae assemblages, more than structural or landscape parameters. In general, the number of significant factors at particular spatial levels did not exceed 3 , which corresponds with other studies concerning Trichoptera (Galbraith et al., 2008; Ruiz-García et al., 2012; Skuja and Spunggis, 2010). At the lowest spatial level -
$\mathrm{pH}$, sediment grain size, insolation and the presence of aquatic macrophytes proved significant for caddisflies, at the highest level (including buffer zones and catchment) - the surface areas of watercourses and the river, distance from standing waters and distance from broadleaf forests, respectively (Fig. 8). The land usage type of the subcatchments revealed an unexpected pattern - higher biodiversity of caddisfly larvae was observed in agricultural areas than in (natural) forests. Trichopteran functional groups (in relation to current and hydrological preferences) showed the best response in detecting gradients of some landscape parameters. Using the Caddisfly Habitat Index (CHI), the following gradient of lateral connectivity of the water body types within the studied river valley was obtained: oxbows - springs - alder carrs - sedge marshes - small water bodies - riverine marshes, indicating the significance of current velocity and high oxygen levels in the oxbows and springs. The values of the $\mathrm{CHI}$ indicated that the dynamics of the water bodies studied was disturbed to a moderate or small degree, and the condition of the entire floodplain system can be considered as good. The results obtained in our study indicate that caddisfly larvae can be used as indicators of different environmental factors, changes and processes. However, they should be analyzed at all possible levels including their organization and spatial structures of the environment.

On the basis of our results, by: i) maintaining the varied structure of aquatic macrophytes in water bodies; ii) securing the long-term presence of broadleaf trees in buffer zones; iii) limiting drainage activities in the river valley; and iv) providing heterogeneous landscape in the river catchment, we can help to preserve biodiversity and ensure sustainable management in river valleys.

\section{ACKNOWLEDGEMENTS}

Financial support for the study was provided by the Ministry of Science and Higher Education in Poland, grant no. N305 222537. We would like to thank to the Reviewer for the valuable comments and a significant improvement of the final version of the paper.

\section{REFERENCES}

Allan JD, 2004. Landscapes and riverscapes: the influence of land use on stream ecosystems. Annu. Rev. Ecol. Evol. Syst. 35:257-284.

Arscott DB, Keller B, Tockner K, Ward JV, 2003. Habitat structure and Trichoptera diversity in two headwater flood plains, NE Italy. Int. Rev. Hydrobiol. 88:255-273.

Aschonitis VG, Feld CK, Castaldelli G, Turin P, Visonà E, Fano EA, 2016. Environmental stressor gradients hierarchically regulate macrozoobenthic community turnover in lotic systems of Northern Italy. Hydrobiologia 765:131-147. 
Biesiadka E, 1980. Water mites (Hydracarina) of the eutrophic Lake Zbęchy (Leszno voiv.). Pol. Ecol. St. 6:247-262.

Bis B, Zdanowicz A, Zalewski M, 2000. Effects of catchment properties on hydrochemistry, habitat complexity and invertebrate community structure in a lowland river. Hydrobiologia 422/423:369-387.

Bonada N, Zamora-Muñoz C, Rieradevall M, Prat N, 2005. Ecological and historical filters constraining spatial caddisfly distribution in Mediterranean rivers. Freshw. Biol. 50:781-797.

Brand C, Miserendino ML, 2011. Characterizing Trichoptera trophic structure in rivers under contrasting land use in Patagonia, Argentina. Zoosymposia 5:29-40.

Camargo JA, Alonso A, De La Puente M, 2004. Multimetric assessment of nutrient enrichment in impounded rivers based on benthic macroinvertebrates. Environ. Monit. Assess. 96: 233-249.

Chovanec A, Waringer J, Straif M, Graf W, Reckendorfer W, Waringer-Löschenkohl A, Waidbacher H, Schultz H, 2005. The floodplain-index-a new approach for assessing the ecological status of river/floodplain-systems according to the EU Water Framework Directive. Large. Riv. 15:169-185.

Cortes R, Varandas S, Teixeira A, Hughes SJ, Magalhaes M, Barquín J, Alvarez-Cabria M, Fernández D, 2011. Effects of landscape metrics and land-use variables on macroinvertebrate communities and habitat characteristics. Limnetica 30:347-362.

Czachorowski S, 1998. [Chruściki (Trichoptera) jezior Polskicharakterystyka rozmieszczenia larw]. [Book in Polish]. Wydawnictwo Wyższej Szkoły Pedagogicznej w Olsztynie, Olsztyn: $156 \mathrm{pp}$.

Duelli P, 1997. Biodiversity evaluation in agricultural landscapes: an approach at two different scales. Agric. Ecosyst. Environ. 62:81-91.

Edington JM, Hildrew AG, 1995. Freshwater Biological Association Scientific Publication, 53. A revised key to the caseless caddis larvae of the British Isles with notes on their ecology. Freshwater Biological Association, Ambleside, Cumbria: 134 pp.

Friday LE, 1987. The diversity of macro invertebrate and macrophyte communities in ponds. Freshw. Biol. 18:87-104.

Galbraith HS, Vaughn CC, Meier CK, 2008. Environmental variables interact across spatial scales to structure trichopteran assemblages in Ouachita Mountain rivers. Hydrobiologia 596:401-411.

Gombeer SC, Knapen D, Bervoets L, 2011. The influence of different spatial-scale variables on caddisfly assemblages in Flemish lowland streams. Ecol. Entomol. 36:355-368.

Goretti E, Tamanti V, Di Giovanni MV, 1995. Trichoptera populations in the water system of the River Tiber in Tuscany and Emilia Romagna (Italy). Ital. J. Zool. 62:297-304.

Graf W, Murphy J, Dahl J, Zamora-Muñoz C, López-Rodríguez MJ, 2008. Distribution and Ecological Preferences of European Freshwater Organisms. Volume 1, Trichoptera. Pensoft, Sofia - Moscow: 388 pp.

Hammer $\breve{R}$, Harper DAT, Ryan PD, 2001. PAST: Paleontological statistics software package for education and data analysis. Palaeont. Electron. 4:1-9.

Heino J, 2000. Lentic macroinvertebrate assemblage structure along gradients in spatial heterogeneity, habitat size and water chemistry. Hydrobiologia 418:229-242.
Heino J, Mykrä H, Kotanen J, 2008. Weak relationships between landscape characteristics and multiple facets of stream macroinvertebrate biodiversity in a boreal drainage basin. Landscape Ecol. 23:417-426.

Hering D, Schmidt-Kloiber A, Murphy J, Lücke S, Zamora-Muñoz C, López-Rodríguez MJ, Huber T, GrafW, 2009. Potential impact of climate change on aquatic insects: a sensitivity analysis for European caddisflies (Trichoptera) based on distribution patterns and ecological preferences. Aquat. Sci. 71:3-14.

Hinkle DE, Wiersma W, Jurs SG, 2003. Applied Statistics for the Behavioral Sciences. $5^{\text {th }}$ edition. Houghton Mifflin, Boston: 784 pp.

Johnson LB, Host GE, 2010. Recent developments in landscape approaches for the study of aquatic ecosystems. J. North. Am. Benthological. Soc. 29:41-66.

Kalaninová D, Bulánková E, Šporka F, 2014. Caddisflies (Trichoptera) as good indicators of environmental stress in mountain lotic ecosystems. Biologia 69:1030-1045.

Kusch J, 2015. Interacting influences of climate factors and land cover types on the distribution of caddisflies (Trichoptera) in streams of a central European low mountain range Insect Conserv. Divers. 8:92-101.

Ligeiro R, Hughes RM, Kaufmann PR, Macedo DR, Firmiano KR, Ferreira WR, Oliveira D, Melo AS, Callisto M, 2013. Defining quantitative stream disturbance gradients and the additive role of habitat variation to explain macroinvertebrate taxa richness. Ecol. Indic. 25:45-57.

Mykrä H, Heino J, Muotka T, 2004. Variability of lotic macroinvertebrate assemblages and stream habitat characteristics across hierarchical landscape classifications. Environ. Manage. 34:341-352.

Palmer MA, Swan CM, Nelson K, Silver P, Alvestad R, 2000. Streambed landscapes: evidence that stream invertebrates respond to the type and spatial arrangement of patches. Landscape Ecol. 15:563-576.

Ruiz-García A, Márquez-Rodríguez J, Ferreras-Romero M, 2012. Implications of anthropogenic disturbance factors on the Trichoptera assemblage in a Mediterranean fluvial system: Are Trichoptera useful for identifying land-use alterations? Ecol. Indic. 14:114-123.

Savić A, Ranđelović V, Đorđević M, Karadžić B, Đokić M, J Krpo-Ćetković, 2013. The influence of environmental factors on the structure of caddisfly (Trichoptera) assemblage in the Nišava River (Central Balkan Peninsula). Knowl. Manag. Aquat. Ecosyst. 409:03.

Skuja A, Spungis V, 2010. Influence of environmental factors on the distribution of caddisfly (Trichoptera) communities in medium-sized lowland streams in Latvia. Estonian J. Ecol. 59:197-215.

Tachet H, Bournaud M, Richoux P., Usseglio-Polatera P, 2010. [Invertébrés d'eau douce - systématique, biologie, écologie]. [Book in French]. CNRS Editions, Paris: 607 pp.

ter Braak CJF, Smilauer P, 2002. CANOCO reference manual and CanoDraw for Windows User's Guide: Software for Canonical Community Ordination (version 4.5.). Microcomputer Power, Ithaca, NY: 500 pp.

Urbanič G, Toman MJ, 2007. Environmental Variables on Stream Caddis Larvae in Three Slovenian Ecoregions: Alps, Dinaric Western Balkans and Pannonian Lowland. Int. Rev. Hydrobiol. 92:82-602. 
Van den Brink FWB, Van der Velde G, Wijnhoven S, 2013a. Diversity, occurrence and feeding traits of caddisfly larvae as indicators for ecological integrity of river-floodplain habitats along a connectivity gradient. Ecol. Indic. 25: 92-98.

Van den Brink FWB, Van der Velde G, Wijnhoven S, 2013b. Seasonal changes in caddis larvae assemblages in riverfloodplain habitats along a hydrological connectivity gradient. Hydrobiologia 716:75-85.

Verberk WCEP, Van Duinen GA, Brock AMT, Leuven RSEW, Siepel H, Verdonschot PFM, Van der Velde G, Esselink H, 2006. Importance of landscape heterogeneity for the conservation of aquatic macroinvertebrate diversity in bog landscapes. J. Nat. Conserv. 142:78-90.

Waldhardt R, 2003. Biodiversity and landscape - summary, conclusions and perspectives, Agric. Ecosyst. Environ. 98: 305-309.

Wallace ID, 1991. A review of the Trichoptera of Great Britain. Research and survey in nature conservation No.
32. Nature Conservancy Council, Northminster House, Peterborough: $59 \mathrm{pp}$.

Wallace ID, Wallace B, Philipson GN, 2003. Freshwater Biological Association Scientific Publication, 61. Keys to the case-bearing caddis larvae of Britain and Ireland. Freshwater Biological Association, Ambleside, Cumbria: 259 pp.

Ward JV, 1998. Riverine landscapes: biodiversity patterns, disturbance regimes, and aquatic conservation. Biol. Conserv. 83:269-278.

Waringer J, Graf W, 2002. Trichoptera communities as a tool for assessing the ecological integrity of Danubian floodplains in Lower Austria. Nova Suppl. Entomol.15:617-625.

Waringer J, Graf W, 2011. [Atlas der mitteleuropäischen Köcherfliegenlarven].[Book in German]. Erik Mauch Verlag, Dinkelscherben: 468 pp.

Zhang Y, Wang B, Han M, Wang L, 2012. Relationships between the seasonal variations of macroinvertebrates, and land uses for biomonitoring in the Xitiaoxi River watershed, China. Int. Rev. Hydrobiol. 97:184-199. 